\title{
A Preliminary Archaeological Survey Along The Medio Creek Drainage, Southwestern Bexar County, Texas
}

\author{
A. Joachim McGraw \\ Center for Archaeological Research
}

Follow this and additional works at: https://scholarworks.sfasu.edu/ita

Part of the American Material Culture Commons, Archaeological Anthropology Commons, Environmental Studies Commons, Other American Studies Commons, Other Arts and Humanities Commons, Other History of Art, Architecture, and Archaeology Commons, and the United States History Commons

Tell us how this article helped you.

This Article is brought to you for free and open access by the Center for Regional Heritage Research at SFA ScholarWorks. It has been accepted for inclusion in Index of Texas Archaeology: Open Access Gray Literature from the Lone Star State by an authorized editor of SFA ScholarWorks. For more information, please contact cdsscholarworks@sfasu.edu. 


\section{A Preliminary Archaeological Survey Along The Medio Creek Drainage, Southwestern Bexar County, Texas}

\section{Creative Commons License}

\section{(c) (1) \&}

This work is licensed under a Creative Commons Attribution-NonCommercial 4.0 International License 


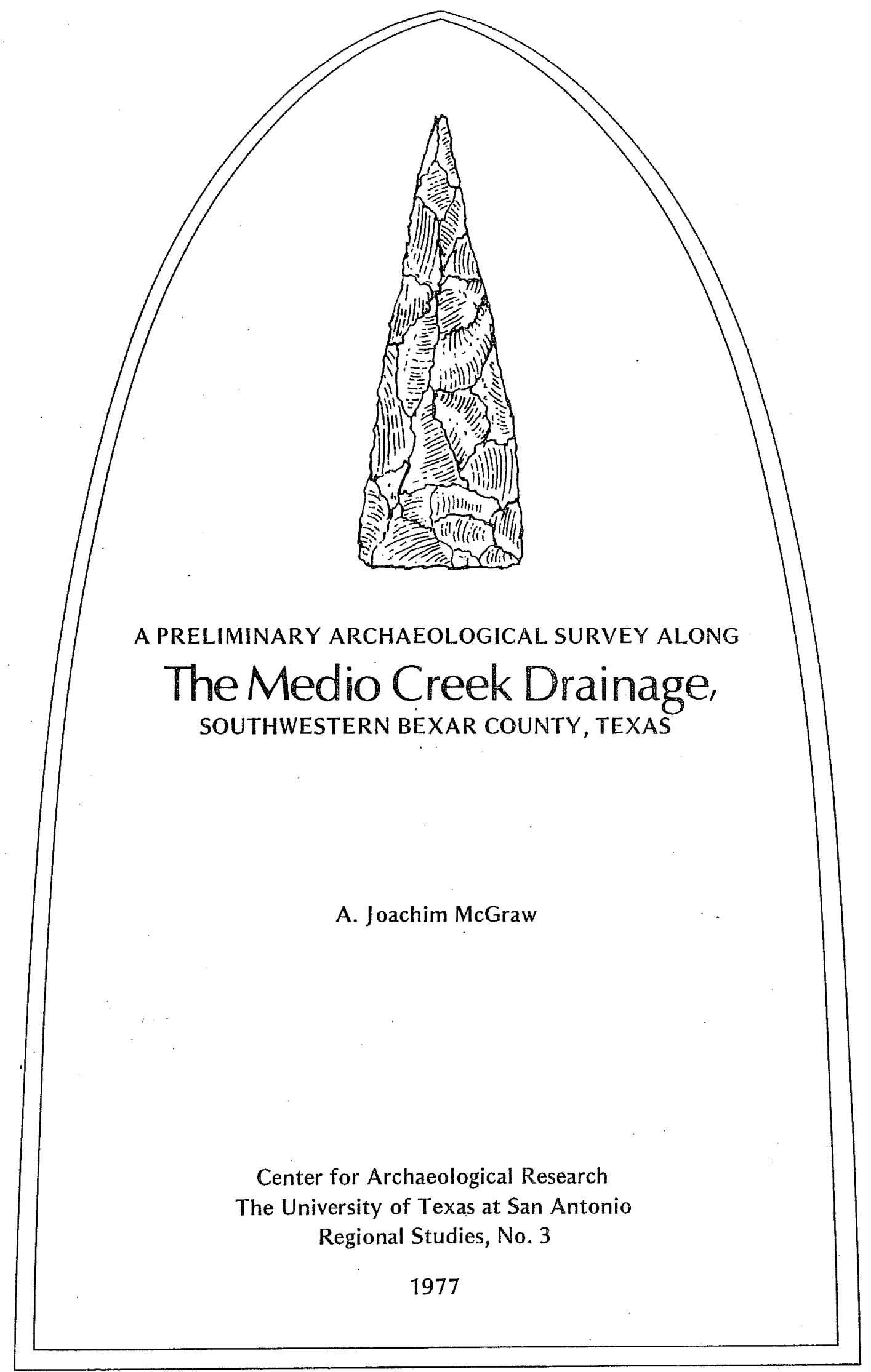




\section{A PRELIMINARY ARCHAEOLOGICAL SURVEY ALONG}

THE MEDIO CREEK DRAINAGE, SOUTHWESTERN BEXAR COUNTY, TEXAS

A. Joachim McGraw

Center for Archaeological Research

The University of Texas at San Antonio

Regional Studies, No. 3 
List of Figures and Tables... . . . . . . . . . . . . ii Preface (Thomas R. Hester) . . . . . . . . . . . . iii Introduction . . . . . . . . . . . . . . . . . . . . . I The Survey . . . . . . . . . . . . . . . . . . . . 1 Physical Environment . . . . . . . . . . . . . . . . . 2 Previous Research and Prehistoric Habitation . . . . . . . . . 4 The Sites . . . . . . . . . . . . . . . . . . 5 The Artifacts . . . . . . . . . . . . . . . . 17 Summary and Recommendations . . . . . . . . . . . . . 32 Acknowledgments . . . . . . . . . . . . . . . . 34 References Cited . . . . . . . . . . . . . . 35 


\section{LIST OF FIGURES AND TABLES}

Figure

Page

1. The Medio Creek Survey Area. . . . . . . . . . . . . 3

2. Views of Site MC $004(41$ BX 461) . . . . . . . . . . . 8

3. Cross Section at MC 008 (4I BX 465) . . . . . . . . . . 11

4. Cross Section Near MC 013 (41 BX 470), MC 014 . . . . . 16 (41 BX 471), MC 015 (41 BX 472).

5. Artifacts from 41 BX 368, 41 BX 459, 41 BX 460, . . . . . . 18 $41 \mathrm{BX} 461$, and $41 \mathrm{BX} 462$.

6. Artifacts from MC 002 (4I BX 459). ............ . 19

7. Artifacts from MC 004 (41 BX 461)............ 20

8. Artifacts from MC 005 (4I BX 462)............. . 21

9. Artifacts from MC 008 (41 BX 465). . . . . . . . . . . 22

10. Artifacts from MC 009 (41 BX 466) and MC 010 ....... 23 (41 BX 467)

11. Artifacts from MC 011 (41 BX 468)............. 24

12. Projectile Points from MC 011 (4I BX 468). . . . . . . . . . 25

13. Artifacts from MC 011 (41 BX 468). . . . . . . . . . . 26

14. Artifacts from MC 011 (4I BX 468). . . . . . . . . . . 27

15. Artifacts from MC 011 (4I BX 468). . . . . . . . . . . . 28

16. Artifacts from MC 013 (41 BX 470). . . . . . . . . . . . 29

17. Artifacts from MC 014 (41 BX 471) and MC 015 ....... 30 (4I BX 472)

18. Artifacts from MC 013 (41 BX 470)............. 31

Table

1. Summary of Recommendations for Future Research . . . . . . . 33 
This volume in the Center's Regional Studies series presents the results of the first scientific archaeological study to be done in southwestern Bexar County. The research was done by the author, A. Joachim McGraw, as a semester project in UTSA's "Texas Archaeology" course (ANT 4113) in Spring, 1977. Like many other parts of Bexar County, the region considered in this monograph is certain to be extensively modified by the continuing spread of housing subdivisions in future years. Thus, this monograph is both an important contribution to the prehistory of south-central Texas, and a significant effort in preserving archaeological information that would have otherwise been lost.

Thomas R. Hester 


\section{INTRODUCTION}

During late February, March and April of 1977, a preliminary archaeological survey was conducted along portions of Medio Creek, an intermittently running waterway in southwest Bexar County. Particular interest in this area focuses around two main elements: (I) the area of Medio Creek and southwest Bexar County in general is very poorly known archaeologically; and (2) suburban development moving westward from the city of San Antonio will shortly destroy or alter major areas of the topography near or on the creek, along with its archaeological resources.

The intent of the survey was to locate archaeological sites in the area and determine their significance and potential before destruction or alteration occurred. This general perspective encompasses an overall view of the creek drainage and possible occupational patterns that might have occurred.

\section{THE SURVEY}

The methodology used in this archaeological survey of Medio Creek was based on techniques and methods outlined in Field Methods in Archaeology (Hester, Heizer and Graham 1975). The investigation was based upon a systematic survey directed toward: (1) location of archaeological sites; (2) a preliminary assessment of their content and importance by surface examination and collection; and (3) detailed recording of site information for future research. Important guidelines followed during this study included: (1) to use as much accuracy as possible in describing, analyzing and evaluating the identified sites; (2) to develop reasonable hypotheses to guide further studies; and (3) to formulate conclusions relevant to cultural processes (Hester, Heizer and Graham 1975:14). In actual practice, the observation of the distribution of materials such as lithic debris was of special importance and was carefully noted not only to define site boundaries but also to locate areas of particular activity. Serious consideration was also given to the presence or absence of particular cultural materials, as well as their location relative to the water source.

The actual survey was conducted during a period of two and one-half months over two- and sometimes three-day periods. Emphasis was not directed at obtaining a complete sample of every area along the creek drainage but was oriented toward a specific research methodology based on time limitations and terrain/ ownership accessibility. Seven areas extending over the entire length of the drainage were chosen because they fit these requirements, and work progressed from these locations. Two areas of interest, a large portion of the midsection of the creek flowing through Medina Air Force Base and an area just to the south of Pearsall Road, were not investigated because of problems in obtaining the owner's permission. That these areas were not studied should be kept in mind since any general conclusions presented by this study are in part compromised by the lack of information from these two areas.

All sites identified along Medio Creek have been recorded on standard site survey forms presently in use by the Center for Archaeological Research of The University of Texas at San Antonio. Black-and-white $35 \mathrm{~mm}$ photographs 
were taken of various sites and features, and all sites were plotted on United States Geological Survey topographic maps. Artifacts were collected at all sites and placed in plastic or paper bags and labeled with temporary site number, site name, date, type of collection and collector's name. Since many property owners expressed an interest in keeping materials from sites on their property, line drawings of selected artifacts from each location were made as permanent recordings.

Since many of the sites identified were comparatively inaccessible without a four-wheeled drive vehicle or without much hiking, a sample of the artifacts through surface collecting was conducted. Controlled surface collection was rejected as too inefficient in both time and manpower, and collections were directed at obtaining samples of diagnostic artifacts, various tools and lithic debris.

\section{PHYSICAL ENVIRONMENT}

The environmental and physiographic conditions of this region are particularly complex; this study will attempt to define only the most relevant elements.

Medio Creek, a tributary of the Medina River, Ilows south from a series of runoff channels in the western margins of the central Texas Hill Country-Edwards Plateau region of Bexar County (Fig. 1). Little more than 16 air miles in length, the creek varies along its drainage in being intermittent, completely dry or freely flowing. Although this preliminary survey did not discover direct causes of this inconsistency, several possible explanations are identified and briefly discussed later in this study. For most of its length, Medio Creek flows roughly parallel to Loop 410 West, and in areas near the Medina River the creek channel reaches depths of 12 to 15 feet and widths of 15 feet.

The survey was divided, somewhat arbitrarily, into three major areas. Each section represented a subtly different morphological distinction of the stream's ecosystem. The northern area encompassed the foothills of the Edwards aquifer and escarpment and extended southward to the area just south of Texas FM 1957 where minor geological changes take place, reflected by a series of gently rolling hills. South of the area of Medina Air Force Base, the topography becomes prairie-like, essentially flat interspersed with an occasional hill; the creek often meanders across the floodplain of the Medina River, where it finally intersects it amid a heavily eroded ridge complex.

The area's elevations range from 540 feet msl along the creek bed to over 920 feet msl in some adjacent upland areas. A number of smal1, usually dry stream beds run into Medio Creek from the northwest.

The climate, like that of the rest of south-central Texas, can be described as sub-tropical. Sumers are hot, winters usually mild with snow a general rarity. Thunderstorms are common in all seasons except winter and these of ten cause serious flooding of all local waterways and low-water areas. 
Figure 1. The Medio Creek Suvey Area.

PAGE 3 REDACTED 
Soils in the area of study generally consist of four soil associations, although this broad description does not reflect the geological complications caused by the drainage system itself in the form of redepositions, erosions, alluviums, rechannelizations, etc. Progressing from south to north, soils can be identified as follows: (I) Lewisville-Houston Black, terrace associated and often eroded with deep clayey soils over calcareous clay and marl; (2) Houston BlackHouston associated, similar to the former but with minor variations; (3) Crawford-Bexar associated, moderately deep stoney soils over limestone; and (4) Tarrant-Brackett, shallow to very shallow soils over limestone. In broader geological terms, the area is located in a stratigraphic transition zone between outcroppings of the Upper Cretaceous (Gulf Series) formations of the Mesozoic Era and the Tertiary (Eocene) formations of the Cenozoic (Taylor et al. 1966).

Biologically, Medio Creek also lies in a transition zone between two distinct biotic provinces, the Tamaulipan to the south and the Balconian in the north. The study area reflects a mixture of flora and fauna from these two regions. Large vegetation includes oak and thorny brush interspersed with mesquite, prickly pear cactus and, often, pecan trees. Typical fauna include a wide diversity of mammals such as armadillo, cottontail rabbit, opossum, squirrel, skunk, gopher, and white-tailed deer. Also present are many different species of fish, birds and reptiles, commonly including rattlesnakes and large water snakes (Blair 1950).

\section{PREVIOUS RESEARCH AND PREHISTORIC HABITATION}

Although Bexar County may be the most archaeologically studied county in south-central Texas with over 400 sites presently recorded, the southwest portion is still poorly known and understood. Prehistoric sites in the county are predominantly open campsites on river terraces, chert workshops, quarry sites, burned rock middens and scatters, and a small number of rockshelters (Woolford 1935; Fawcett 1972; Hester 1975:5).

The time periods represented range from Paleo-Indian (ca. 9200-6000 B.C.) to the Neo-American/Late Prehistoric (A.D. 1200 to historic contact) but with the Archaic period (ca. 6000 B.C.-A.D. 1200) predominant. Unfortunately, a major problem in this area is the lack of a definitive chronology, which often retards the growth of understanding of these periods. Although there are many sites and abundant lithic materials, little is known about the hunting and gathering cultures that inhabited the study area. The introduction of the bow and arrow abruptly modified the artifact assemblages; small arrow points of distinctive styles, new lithic forms, and occasional bone-tempered ceramics made their appearance after A.D. 1200.

At the time of European contact, South Texas was inhabited by small groups of semi-nomadic hunting and gathering groups thought to share a common language, "Coahuiltecan." This simplistic aggregation and assumption of common traits has come under contemporary criticism and it has become evident that many differences, including cultural and Iinguistic, existed among the groups. By the 18 th and 19 th centuries these indigenous groups were decimated by 
diseases, assimilated, or "missionized" into oblivion. Intrusive Plains Indians became an important factor in the history of the period as Lipan Apache and, later, Comanche groups moved into the region (Nunley and Hester $1975: 8-9)$.

THE SITES

Site designations usually follow the trinomial identification in which the first number represents Texas, the next two letters the county, and the last numbers a specific site. Throughout most of this study, however, only tempcrary site designations were used. When sites were first encountered during the survey, two letters (MC) were applied denoting Medio Creek and these were combined with a sat of three numbers to identify a particular site.

Locational information is given only to locate the site in a general environmental and geographic context. Specific locations are not generally given, in order to forestall improper use of such information (Nunley and Hester 1975: 11). Detailed maps are on file at the Center for Archaeological Research.

Site descriptions will generally follow the format presented below.

Location: Viewed from a general geographic and environmental context and in respect to known geographic features.

Elevation: Elevation above Mean Sea Level (msl) as identified through U.S.G.S. topographic maps.

Description: Brief, specific statements concerning the site occupation, depth, extent, and condition.

Type of site: Occupational (campsite), quarry, workshop, temporary occupation, stream terrace, multifunctional, etc.

Environmental characteristics: A brief geographic and environmental description. Interpretation/Remarks: A preliminary analysis of the extent, importance, and condition of the site.

\section{001 (41 BX 368; Cindy Mae Site)}

Location: Site area follows the contours of a former stream terrace behind the entrance to Hidden Valley Recreational Park, southwestern Bexar County.

Elevation: $550-580$ feet msl.

Description: Physically, the site follows the contours of the ridgeline and culminates in a large, relatively high bluff to the south while the northern end is bounded by a large eroded area consisting of light calcareous marl interspersed with cobbles of varying size. The site extends north-south ca. $300 \mathrm{~m}$ and slopes westward and downward ca. $250 \mathrm{~m}$ toward Medio Creek. Site 41 BX 368 includes two artifact concentrations upon the southern bluff and at least three fire-burned rock scatters on the ridge below it, the scatters situated atop eroded knolls. 
Type of site: Archaeological evidence in the form of finished bifaces, scrapers, a projectile point, Iithic debris and fire-burned rocks suggests a multifunctional site including habitation and workshop areas.

Environmental characteristics: The site area is generally covered by high grasses and is presently used as a horse pasture. Uplands extend northeastward away from the creek area. Solls are characterized by heavy gully erosion on slopes, dark grey loam on uplands, and eroded calcareous marl mixed with cobbles on slopes. Vegetation along the stream channel includes high grasses, oak, pecan, elm, mesquite and often dense brush.

Interpretation/Remarks: Heavy erosion has badly damaged slope sections of the site, especially near the base of the bluff; but the presence of some halfburied material on the bluff area itself suggests that some controlled surface collection may be feasible at this site.

MC $002(41$ BX 459)

Location: Ca. $400 \mathrm{~m}$. NW of $41 \mathrm{BX} 368$ on the fringes of a high ridge adjacent to former crescent-shaped channel and floodplain of Medio Creek. Located on the eastern bank of the stream, the site overlooks a bowl-shaped depression ca. $275 \mathrm{~m}$ in diameter.

Elevation: 620 feet msl.

Description: An "extensive" rather than intensive area, the site can best be described as an extensive preferred occupational zone rather than a locally defined and limited area. Lithic debris is scattered frequently along the high ground for more than $300 \mathrm{~m}$ and ranges at least $100 \mathrm{~m}$ eastward away from the waterway into dense brush. A major feature is ca. $12 \mathrm{~m}$ north of the fenceline that composes the southern boundary of the site; a small crescentshaped midden ca. $5 \mathrm{~m} \mathrm{x} 3 \mathrm{~m} \times 25 \mathrm{~cm}$ in height. Several fragments of a large brushed potsherd have been found eroding from this feature. Bifaces and two projectile points, identified as Frio and Gower, have also been found within $5 \mathrm{~m}$ of this area. Fire-cracked rocks are scattered throughout.

Type of site: Possibly multi-functional, primarily occupational. Possible "base area."

Environmental characteristics: High, dense brush obscures much of the site. MC 002 is located on the edge of an upland ridge complex liberally overgrown with thorn bushes, tall grasses, and much mesquite. Soils are dark grey but the eroding slope is tan calcareous marl.

Interpretation/Remarks: $\quad M C 002$ is a potentially important site primarily because of the ceramic fragments found. They appear to represent the Boothe Brushed type (Dee Ann Story, personal communication), a minor central Texas ware rarely found in southern or south-central Texas. Since the fragments were found in situ eroding from the midden area, it is possible that further testing may uncover more sherds. 
MC $003(47$ BX 460)

Location: Ca. $200 \mathrm{~m}$ directly southwest and across the stream channel from 41 BX 368, on Flat, high ground ca. 11 m above the west bank of Medio Creek. Elevation: 580-590 feet msl.

Description: The site covers an area of ca. $200 \mathrm{~m}$ east-west and over $200 \mathrm{~m}$ north-south. The area has been critically altered by chain-dragging and bulldozing. Very few artifacts have been found on the open level ground but there are frequent scatterings of heat-fractured rocks, chert flakes, and biface fragments along the northern boundary of the site, a fenceline which separates the open area from heavy brush beyond. The presence of archaeological evidence beyond the fenceline implies the site may extend further to the north where it may be less damaged. Artifacts from MC 003 include a large, thin, finely worked biface ca. $10 \mathrm{~cm}$ in length, several large burned rocks, and a predominance of secondary and tertiary flakes. No features were noted in the open area.

Type of site: Finished tools and heat-fractured rock suggest a moderately occupied habitation site.

Environmental characteristics: Much erosion has taken place along the slopes of the site and the site area itself has been modified by recent activity in the form of land clearing. The area just to the north consists of heavy brush, mesquite trees and other upland vegetation. Soils are dark to medium grey loams eroding on the slopes to a lighter grey and a tan calcareous marl.

Interpretation/Remarks: MC 003 has been extensively damaged but the frequency of artifacts along the northern fenceline suggests the site may extend undamaged further north into the brush. The relative closeness to $41 \mathrm{BX} 368$ to the east, especially to the bluff areas, may indicate some relationship. Without further diagnostic evidence, however, such a relationship is unknown.

MC 004 (41 BX 461; Fig. 2)

Location: $300 \mathrm{~m}$ southwest of MC 003 on the same ridge complex but separated from it by a ca. $100 \mathrm{~m}$ wide, deeply eroded gully. The site is bounded on the north by a common fenceline, ca. $80 \mathrm{~m}$ from the southern slopes of the site.

Elevation: 580 feet msl.

Description: Very similar to MC 003 in shape, it shares a common northern boundary, an east-west running fenceline. Unfortunately, even in early spring, the entire site area, ca. $275 \mathrm{~m}$ in length, is heavily overgrown with high tal1 grasses (sometimes called buffalo grass). This vegetation tenaciously resists any attempts to clear ground cover (short of burning or plowing) and obscures over $90 \%$ of the site area. This condition precludes any attempt at defining site boundaries although lithic debris found in widely scattered, ant-cleared, circular spaces across the site suggests the site may extend north into uncleared brush. No features were noted but an intense lithic debris concentration ca. $15 \mathrm{~m}$ 


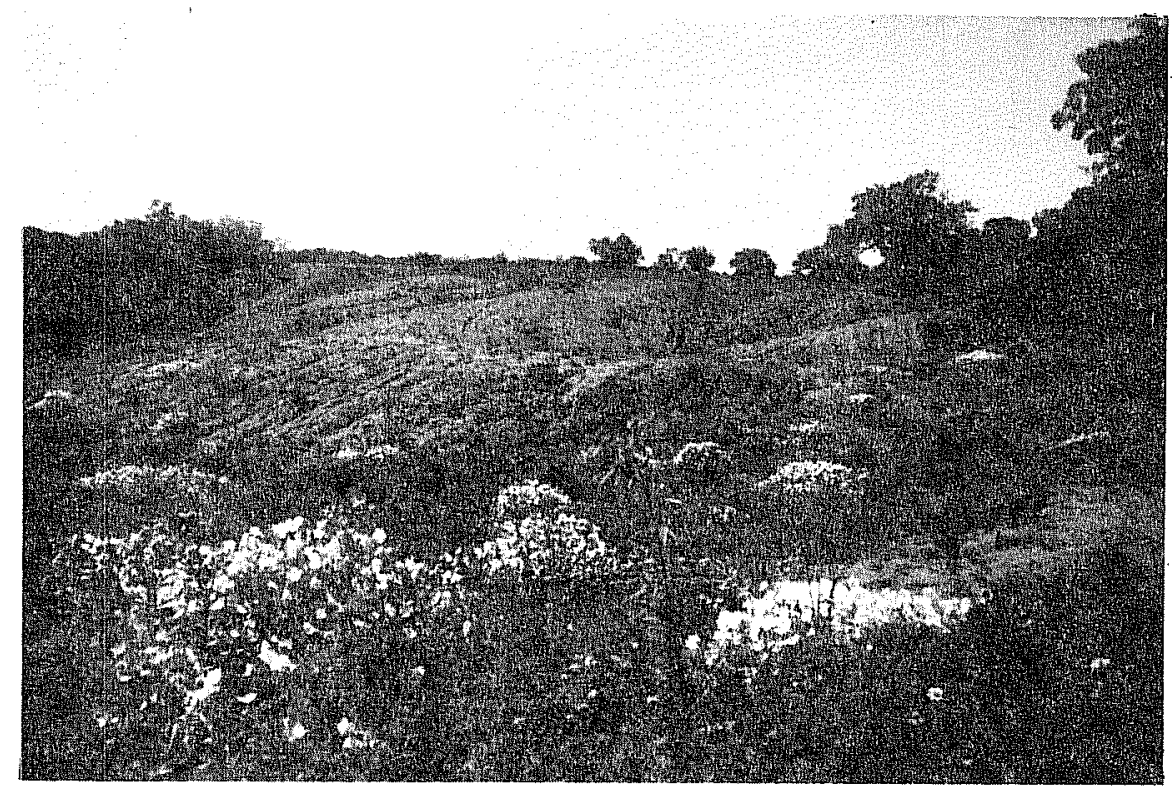

a

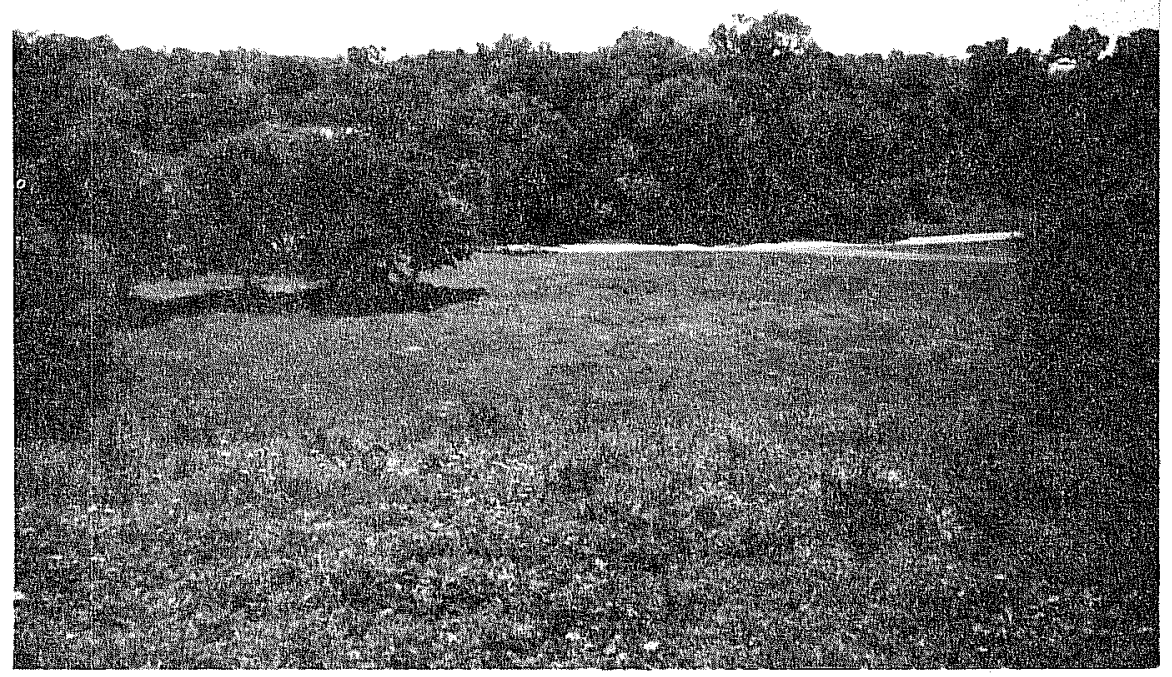

b

Figure 2. Views of Site MC 004 (41 BX 461). a, view from the east; $b$, view from the edge of the southern slope eastward across fossil floodplain of Medio Creek. 
in diameter was located just east of, and in part into, an unpaved road which winds its way up the steep southern slope from the floodplain below. The concentration contained primary, secondary and tertiary flakes, several thin biface fragments and one small pottery fragment. Although only $1 \mathrm{~cm}$ in length, the exterior surface of the ceramic artifact is plainly visible and shows no evidence of any of the brushstroking found on the sherds in MC 002 . Exterior surface of this small fragment is smooth and undecorated. No features were noted at the site.

Type of site: Multi-functional; occupational/workshop.

Environmental characteristics: As mentioned, high grasses hide much of the ground surface. Otherwise, the area is clear of any large trees or other types of vegetation. Much erosion is presently taking place on the eastern and southern slopes. Beyond the northern fenceline lies dense brush of upland vegetation. MC 004 itself is located on a flat, high ridge system adjacent to a former channel of Medio Creek but over $30 \mathrm{~m}$ above the floodplain.

Interpretation/Remarks: Like nearby MC 003, this site has been heavily damaged by chain-dragging and bulldozing. However, the presence of eroding artifact concentrations along the southern slope suggests portions of the site may still be intact. MC 004 is unique in that its steep southern slope overlooks a former channel and floodplain area of Medio Creek. Today, this location is simply a small valley in an eroded ridge-valley complex; the creek has been rechanneled to flow further south and west behind another set of ridges. Ceramic evidence at this site may warrant a more intensive survey of the southern slope area and into the dense brush to the north.

MiC 005 (47 BX 462; Pool Hall Site)

Location: Within the confines of the Hidden Valley Recreation Park, south of Fischer Road, southern Bexar County. Situated atop a high, flat ridge and overlooking not only the roadway and structures but much of the park as well, it is bounded on the east, ca. $100 \mathrm{~m}$, by a north-south fenceline. Upland continues to the north and east, and a heavily eroded, steep ridge is located to the west and south.

\section{Elevation: $570-580$ feet msl.}

Description: MC 005 overlooks the floodplain of Medio Creek. The entire high ground area atop the ridge, ca. $120 \mathrm{~m} \mathrm{X} 100 \mathrm{~m}$, contains a scattering of lithic debris, some characterized by potlids, heat fractures, and fire-reddened discolorations. A small but scattered concentration occurs just above and to the northeast of the building structures below. No evidence of features or finished artifacts occurred but there were occasional samples of firefractured cobbles.

Type of site: Light to moderate occupation, but the amount of lithic debris suggests primary use as a lithic workshop.

Environmental characteristics: High grasses grow on most of the surface with an occasional mesquite tree. The slope to the south and west is heavily eroded exposing frequent chert cobbles. At least the southern half of the site has been altered by brush clearance and/or bulldozing. Soils are medium grey 
exposing frequent chert cobbles. At least the southern half of the site has been altered by brush clearance and/or bulldozing. Soils are medium grey turning lighter on slopes.

Interpretation/Remarks: MC 005 suggests use of limited high ground area adjacent to the waterway as a lightly occupied site in which the primary function was some degree of lithic activity. Due to the absence of diagnostic tool types, projectile points, or other artifacts associated with habitation, further survey work here is considered unnecessary.

\section{NC $006(41$ BX 463)}

Location: Directly east of an unpaved roadway, situated atop a high knoll in Hidden Valley Recreation Park, south Bexar County. Distance from park entrance along roadway to knoll is 0.5 mile.

Elevation: 610-620 feet msl.

Description: A roughly oval site ca. $50 \mathrm{~m}$ east to west by 75 m north to south. This unusually high ground has a light scattering of lithic debris along the edges of its eastern and western slopes. Artifact evidence consisted of an occasional fire-reddened rock and generally secondary or tertiary flakes. No finished artifacts or features were noted.

Type of site: Lithic workshop.

Environmental characteristics: These consist of dense vegetation in the form of thorn bushes, mesquite trees, prickly pear cactus, and assorted high grasses. One of the higher elevations in the vicinity, this site overlooks much of the surrounding area. Soils are colored medium grey ranging to darker shades.

Interpretation/Remarks: From preliminary estimates, MC 006 is identified as a lightly used lithic workshop site having little artifactual remains. Whether this is due to previous erosion or lack of aboriginal use cannot now be determined.

MC $007(41$ BX 464)

Location: In the area of Hidden Valley Recreation Park, south Bexar County. Site area extends 400 to $450 \mathrm{~m}$ along a steep ridgeline that runs parallel and to the east of Medio Creek.

Elevation: $570-590$ feet msl.

Description: The site area extends ca. 400-450 m north-south along the upland ridge to the east of Medio Creek and at an approximate distance of 15-20 m up a steep slope. Archaeological evidence in the form of lithic debris gradually disappears by traveling ca. $70 \mathrm{~m}$ east away from the edge of the ridgeline. The unusually large site contains primary, secondary and tertiary flakes in a large and frequent scattering along its entire length without any particular concentrations. There are occasional traces of small, solitary fire-cracked rocks, chunks 
and cores. Although covered by heavy brush, thorn bushes, mesquite trees and tall grasses, a comparatively enthusiastic exploration was launched but produced no evidence of finished artifacts or features. Survey efforts produced little more than unbiased random samplings of chiggers throughout the site. Soils were medium to dark grey, with numerous cobbles eroding from the gullies and washes to the west of the ridge.

Type of site: Lithic workshop, possibly lightly occupied.

Environmental characteristics: MC 007 is characterized by an extensive ridge system bordered on the west by a steep slope and overlooking Medio Creek. The western slope often exposes deeply eroded gullies and washes with large amounts of chert cobbles. The ridge climaxes to the south in a high bluff overlooking the mergence of Medio Creek and the Medina River. Toward the north upland topography predominates with heavy brush covering much of the highly elevated areas. Of the upland area, 30-40\% lacks tree vegetation and is covered only by tall grasses.

\section{008 (41 BX 465; Stolte 1; Fig. 3)}

Location: North of Highway 90 along west bank of Medio Creek, extending from a nearby fenceline which runs north-south ca. $100 \mathrm{~m}$ east toward the channel. The site is adjacent to and east of a fenceline which separates a plowed field from a heavily overgrown field.

Elevation: 705 feet msl.

Description: While generally following the contours of the stream terrace, the site itself is ca. $350 \mathrm{~m}$ (north-south) by $100 \mathrm{~m}$ (east-west) in an irregularly shaped oval. The area consists of a scattering of large cores and worked blanks, often more than $16 \mathrm{~cm}$ in length. Smaller items of 1ithic debris were also common over the area. No evidence of occupation was identified other than several large fire-cracked rocks, most scattered in the northeast section of the site and generally within $25 \mathrm{~m}$ of the creek. Most artifacts were located on either of two terraces on the west bank of the creek, identified as terraces $I$ and $I V$.

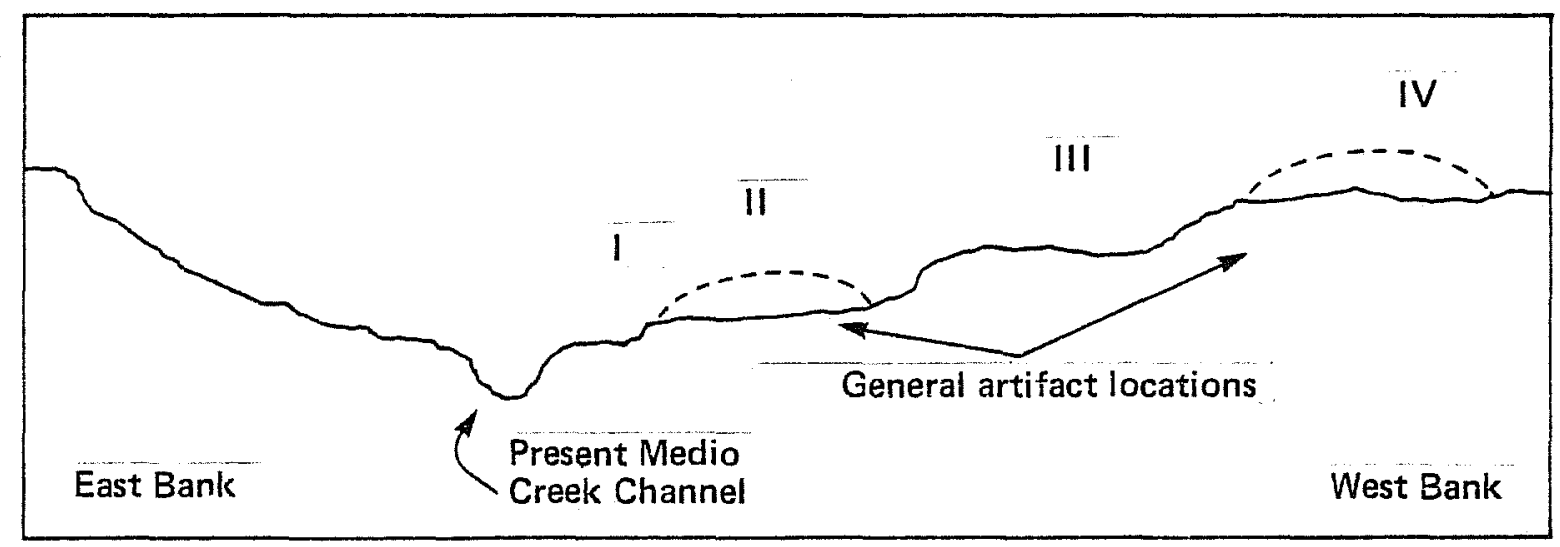

Figure 3. Crass Section at MC 008 (41 BK 465). 
East of the creek, the bank consisted of a level terrace and then sloped sharply eastward, covered by heavy vegetation. Soils were very rocky, medium brown to grey with darker alluvium nearer the channel. Only two trees were located on the western bank and vegetation was little more than medium grasses.

Type of site: Primarily lithic workshop, possibly light occupation.

Environmental characteristics: MC 008 is characterized by a broad, gently sloping set of terraces along its west bank and a steeply rising, heavily wooded east bank. The creek is from 6 to 10 feet wide in this area and seems to be constantly flowing. The upland margins away from the creek are characterized by dark grey to black soils containing numerous chert cobbles of varying sizes. Just north of the area, Medio Creek is fed by a series of run-offs which flow outward or downward from the ridge system to the northeast. The run-offs form a marshy area adjacent to and just north of the creek. These run-offs may be a primary cause of the high water level and continual flowage of the creek further south. Causes for the feeder streams were not identified but several possibilities are discussed later in this study.

Interpretation/Remarks: While not a site of great potential, MC 008 occupies an important location in the mid-region of the drainage and reflects an environmental transition area between the foothills of the escarpment to the north and the flat, slightly rolling topography to the south. In such a transition zone, any archaeological evidence would be of both interest and value in attempting to establish occupational patterns along the drainage.

MC 009 (41 BX 466; Crazy Quail Site)

Location: Within the property of the "Sportsman's Range," an outdoor rifle, pistol and shotgun range just west of Texas FM 1604, 0.8 mile south of the intersection of Texas FM 1957 and 1604.

Elevation: 780 feet msl.

Description: Site area generally covers the area of higher ground on a small knoll. Dimensions are ca. $75 \mathrm{~m}(\mathrm{~N}-\mathrm{S})$ by $30 \mathrm{~m}(\mathrm{E}-\mathrm{W})$. High, dense brush obscures the northern section of the site but artifact evidence suggests that part of the site extend into this zone. Although the boundaries are tenuous, the flat area of the knoll is roughly rectangular in shape. Archaeological evidence consists of several finished tools including a thin, triangular biface $7.5 \mathrm{~cm}$ in length, two bifacially worked scrapers, and a uniface. At least four slight rises, ca. 3-5 $\mathrm{m}$ in diameter each, are also situated atop the knoll. The site, however, does not contain any frequent amount of surface lithic debris. Although an occasional finely fractured rock was noted, there was no evidence of concentrations or large fire-reddened rocks. Soils were colored dark brown ranging to light with frequent outcroppings of limestone formations above a thin soil layer.

Type of site: A sma11, light to moderately occupied habitation site. 
Environmental characteristics: The knoll is located at the branching of Medio Creek and a dry tributary which winds its way westward for another 1.5 mile. The main channel of Medio, also dry, turns northward toward the Edwards aquifer and escarpment zone. Topography is higher here than Iurther to the south with prominent rolling hills and gradual but extensive sloping of ridges. Soil cover is shallower and outcroppings of limestone formations are common both along the creek bed and in the uplands. Behind the site and to the west rises a large ridge complex characterized by upland flora and fauna. Vegetation in the vicinity of the site includes tall grasses, oak, much mesquite and some pecan trees scattered along the creek to the north.

Interpretation/Remarks: $M C 009$ is a localized site physically distinct from the extensive "artifact zones" to the south. Whether this is a reflection of activity based on environmental or cultural processes is beyond the scope of this study.

\section{MC $010 \quad(41$ BX 467)}

Location: Ca. $300 \mathrm{~m}$ upstream from MC 009 and along the main channel of the dry creek bed, it is located on the west bank of a former stream terrace.

\section{Elevation: 770 feet msl.}

Description: Because of the dense brush, thorn bushes, numerous trees, grasses and reeds often reaching five feet in height, and the constant threat of unfriendly reptiles along the creek channel, the proper limits of this site were never identified. The site was located by observing several large firecracked rocks scattered along a small slope on the west bank of the creek. Closer examination revealed the presence of secondary and tertiary flakes. Expended cores were also found eroding from the bank ca. $2 \mathrm{~m}$ above the channel. No features or concentrations were noted, although finely fractured cobbles were scattered in a circular area ca. $6 \mathrm{~m}$ in diameter in the vicinity.

Type of site: Light occupation, possibly lithic workshop.

Environmental characteristics: All factors considered, MC 010 was located in one of the most inaccessible areas of Medio Creek. The earliest route of travel was simply to travel up the dry creek bed which was overgrown with high grasses and interspersed with rocky ledges and bushes. The unusually common occurrence of rattlesnakes during this survey period added a dimension of excitement not found in the average archaeological study.

Interpretation/Remarks: While the actual site size was not determine, artifact concentrations along and below the bank suggest a limited site area not exceeding $50-60 \mathrm{~m}$ in length along the channel. The estimated size and its close proximity to the creek are characteristics not usually encountered in preliminary survey work to the south. 
MC 011 (41 BX 468; R. H. Tucker Site)

Location: Property of R. H. Tucker, adjacent to Medio Creek ca. $50 \mathrm{~m}$ east of Talley Road, West Bexar County.

Elevation: $840-850$ feet msl.

Description: The site runs the entire length of the property along Medio Creek, ca. $100 \mathrm{~m}$ northeast, and extends at least $75 \mathrm{~m}$ north away from it. Although the site has been altered or in part destroyed by suburban development, various artifacts casually collected by the Tucker family since the mid-1960s now compose an impressive collection including an imposing array of large bifaces, other lithic tools, debris and projectile points. Dart and arrow points are made from a wide variety of naterials and include nonlocal forms of fine-grained chert and quartz. The total artifact collection remains uncounted but includes ca. 30 large bifaced tools, an array of projectile points that encompass the Archaic period, and dozens of small arrow points of Late Prehistoric occupations. A preliminary identification of diagnostic dart points includes Pedernales, Marshall, Montell, Early Corner Notched, Ensor, Frio, Kinney, and Perdiz, among others. Large fire-crazed, potlidded, and burned rocks, numerous samples of fractured cobbles, and lithic debris are scattered over the area. A low but prominent rise in the northeast corner of the property ca. $15 \mathrm{~m}$ in diameter and $15 \mathrm{~m}$ from the creek composed the only feature of the site. Artifact depth in some areas of the site may exceed $76 \mathrm{~cm}$; the owner relates he has recovered dart point fragments at this level recently while laying a pipeline.

Type of site: Major occupation.

Environmental characteristics: MC 011 is located on the north bank of Medio Creek on a broad stream terrace. The creek, even when intermittent in this area, forms a natural pool adjacent to the site. Terrain features have been modified, altered, or destroyed by suburban development and the area is now covered by neatly mowed carpet grass. The south bank of the creek culminates in a high overhang of limestone outcropping 3 to $4 \mathrm{~m}$ higher than the north bank. Areas to the northwest along the waterway rapidly erode into precipitious bluffs and steep slopes. Soils along the site area are alluvial, brown to dark brown in color.

Interpretation/Remarks: Although critically altered as a site, MC 011 deserves special attention not only because of its large collection of artifacts but also because the intensity of occupation suggests environmental factors attracting different hunting and gathering groups across a wide expanse of time.

MC $012(41$ BX 469)

Location: Ca. $400 \mathrm{~m}$ west of Talley Road along Medio Creek, upstream from MC 011.

Elevation: $850-860$ feet msl. 
Description: The site is roughly oval ca. $150 \mathrm{~m}$ in length and extending ca. 60 m north away from the creek. Archaeological evidence is limited to a light-to-moderate scattering of lithic debris incluaing many secondary and tertiary flakes. No features or concentrations were noted.

Type of site: Light activity as lithic workshop.

Environmental characteristics: Present day characteristics are similar to MC 011 downstream. Both have pools of water when most of the creek is dry, both are located on the same stream terrace, and both are adjacent to a high limestone ridge across the creek. Vegetation is characterized by high grasses and groves of oaks. Even today wild ducks and small mammals are common throughout the area. MC 012 is located on the southern margins of a low flat area which eventually and gradually slopes slightly upward ca. 300-350 m toward the north.

Interpretation/Remarks: Superficially at least, MC 012 appears environmentally similar to MC 011 but lacks the intensive evidence of aboriginal occupation.

MC 013 (41 BX 470; Fig. 4)

Location: 0.25 mile west of entrance to the Stolte estate and along the west bank of Medio Creek, west Bexar County. The site extends south from the eastwest fenceline that separates light grasses from heavy brush.

Elevation: 850-860 feet ms1.

Description: Roughly a long oval, site dimensions are ca. $230 \mathrm{~m}$ (north-south) by 70-80 m (east-west). Archaeological evidence includes a large, thin biface more than $12 \mathrm{~cm}$ in length, three dart point fragments of unknown diagnostic types, and a scattering of lithic debris throughout the area. Two small concentrations were noted, each ca. $5 \mathrm{~m}$ in diameter. Concentration A is located ca. $35 \mathrm{~m}$ west of the creek and ca. $3 \mathrm{~m}$ from the formerly mentioned fenceline. Concentration $B$ surrounds the gate entrance area to an open field ca. $40 \mathrm{~m}$ from the west bank of the creek and ca. $200 \mathrm{~m}$ south of Concentration A. Thick grasses block much of the surface around Concentration B. Both concentrations contain scatterings of lithic debris and bifacial fragments. Directly opposite MC 013 on the east bank is a light scattering of secondary and tertiary flakes. Since no finished or diagnostic artifacts, features or concentrations were noted on the east bank, it was considered only a "fringe area" for the purposes of this survey.

Type of site: Multi-functional, primarily occupation with moderate 1 ithic workshop activity.

Environmental characteristics: The site is characterized by a large pool of standing water $\mathrm{ca} .80 \mathrm{~m}$ in length adjacent to MC 013 . The most noticeable terrain feature is the relatively high knoll on the east bank directly across from MC 013. The entire length of the site is characterized by moderate brush and overgrown with high grasses, but horses and cattle have cleared trails through this. The west bank extends without much rise in elevation ca. 900 m westward toward a series of steep ridges. 


\section{015}

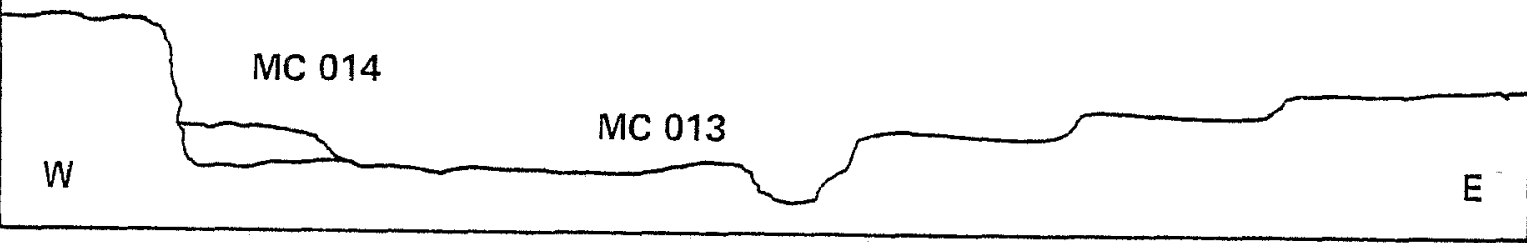

Figure 4. Cross Section Near MC 0.13 (41 BX 470), MC 014 (41 BX 471), MC 015 (41 BX 472).

Interpretation/Remarks: Like MC 011 , MC 013 is an occupation site with close proximity to the creek. It is the first moderately extensive occupation site from the Tucker site located more than a mile downstream. It is also the only occupational site near the creek bank for at least an equal distance upstream.

MC $014(41$ BX 471; Fig. 4)

Location: Situated on a high knoll 0.5 mile west of entrance to Stolte estate. An unpaved road leads to the knoll on which stand the Stolte residence, garages, and chicken coop.

Elevation: $870-880$ feet msl.

Description: Almost totally destroyed as an archaeological site, MC 014 is buried beneath the Stolte house and associated buildings. Numerous projectile points and fragments have been found around the house and a somewhat scattered artifact concentration encompasses the area of a chicken coop. At least six complete or near-complete dart points have been recovered from this confined area little larger than $2 \times 3 \mathrm{~m}$. Surrounding the coop and several meters to the south are scattered numerous flakes, small cores, and chips.

Type of site: Occasional fire-cracked rocks in the vicinity suggest an occupation site.

Environmental characteristics: Located ca. $270 \mathrm{~m}$ to the west of MC 013, the site j.s located on a natural knoll at least $6 \mathrm{~m}$ higher than any other feature in the vicinity in the area of the floodplain. Extensive modern modification of the terrain has altered the vegetation patterns but the knoll is still the most prominent fature within 1000 m of either bank.

Interpretation/Remarks: The knoll site may have been a more intensive area of occupation than nearby MC 013; however, contrasting projectile point styles may suggest different temporal associations. 


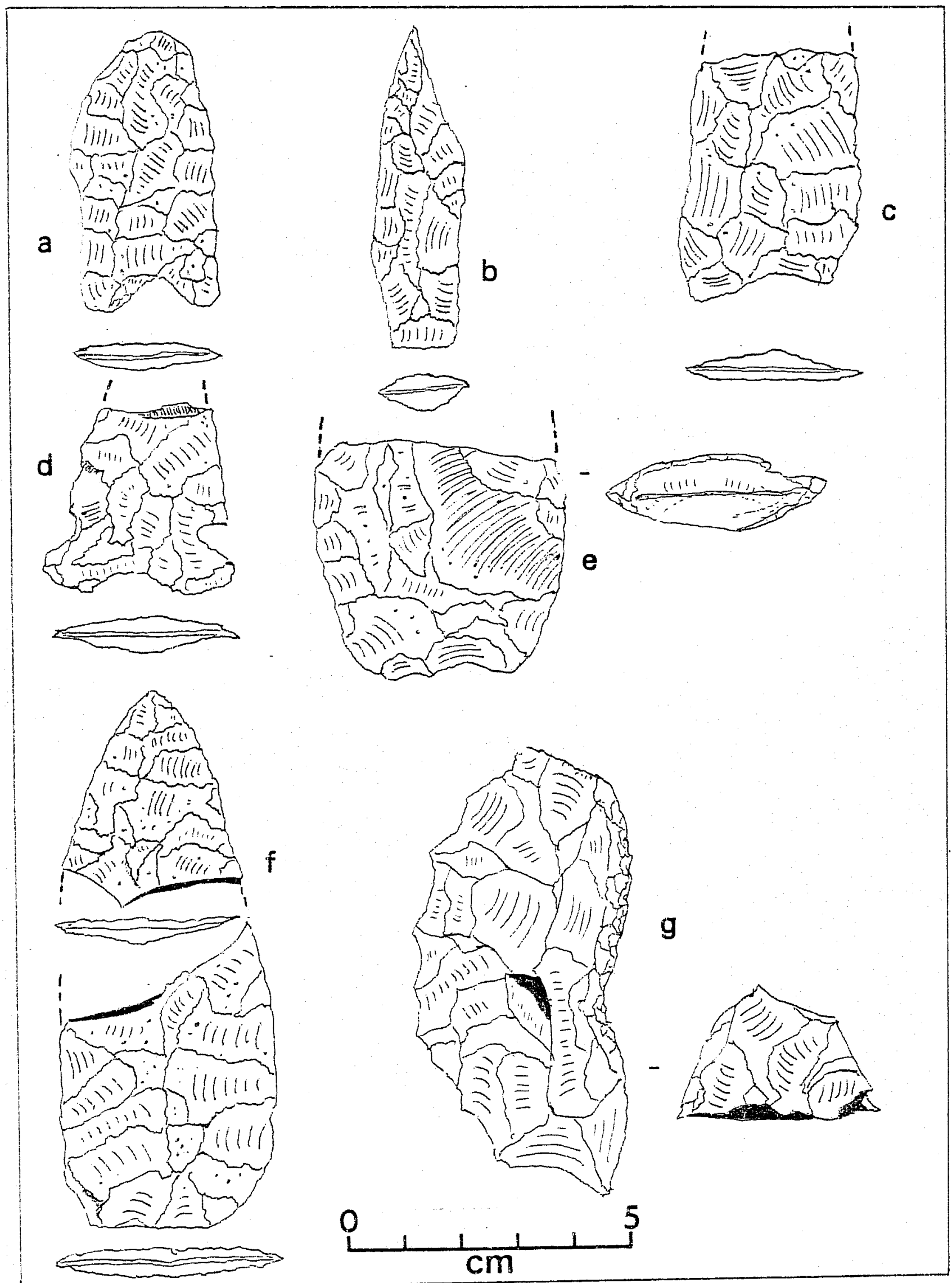

Figure 5. Artifacts from 41 BX 368, 41 BX 459, 41 BX 460, 41 BX 461, and 41 BX 462. a, 41 BX 459, Gower-like projectile point; b, lanceolate point, 41 BX 368; c, distal portion of biface, 41 BX 460; d, Frio, 41 BX 459;

e, distal portion of biface, $41 \mathrm{BX} 368$; $f$, large biface fragments, $41 \mathrm{BX} 461$; $\circ$ GlindinPlino-1ike tant $41 \mathrm{RX}$ LE? 


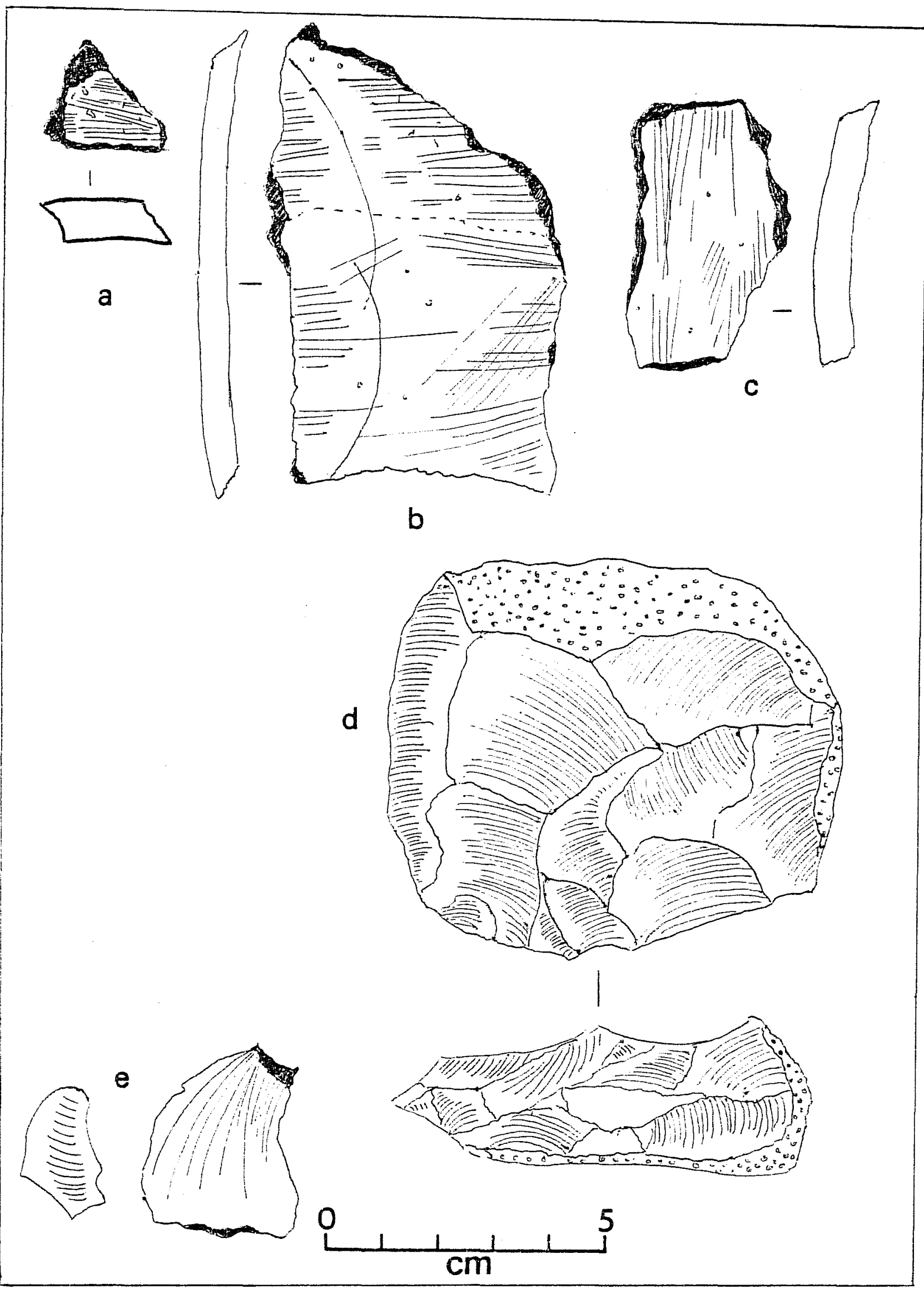

Figure 6. Artifacts from MC 002 (41 BX 459). a-c, Boothe Brushed pottery fragments; $d$, bifacial scraper; e, shell fragments. 

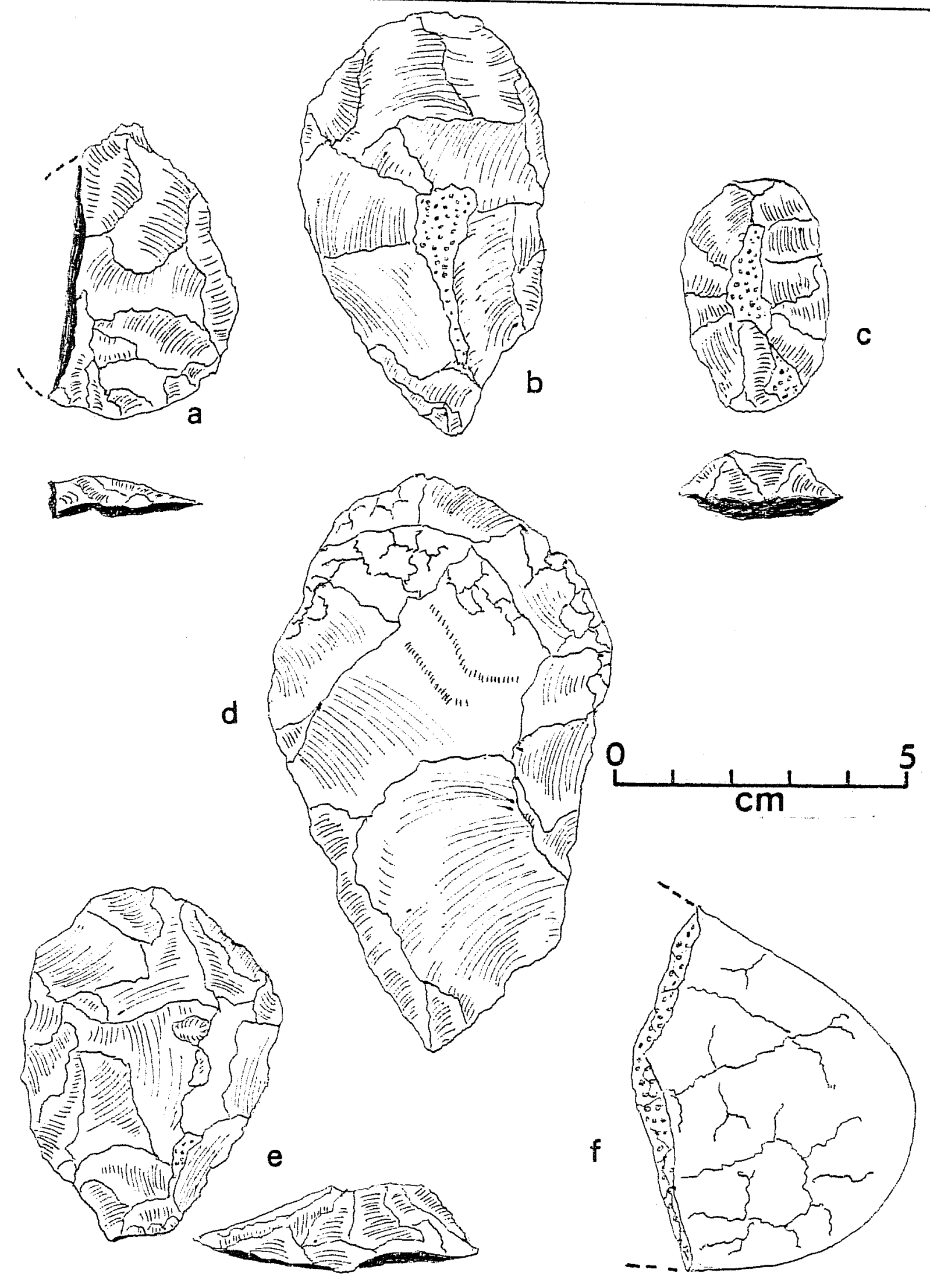

Figure 7. Artifacts from MC 004 (47 BX 461). a, thin oval biface fragment; $b$, thick biface; c, small core; d, large biface; e, thick biface; f, finely fractured cobble fragment. 


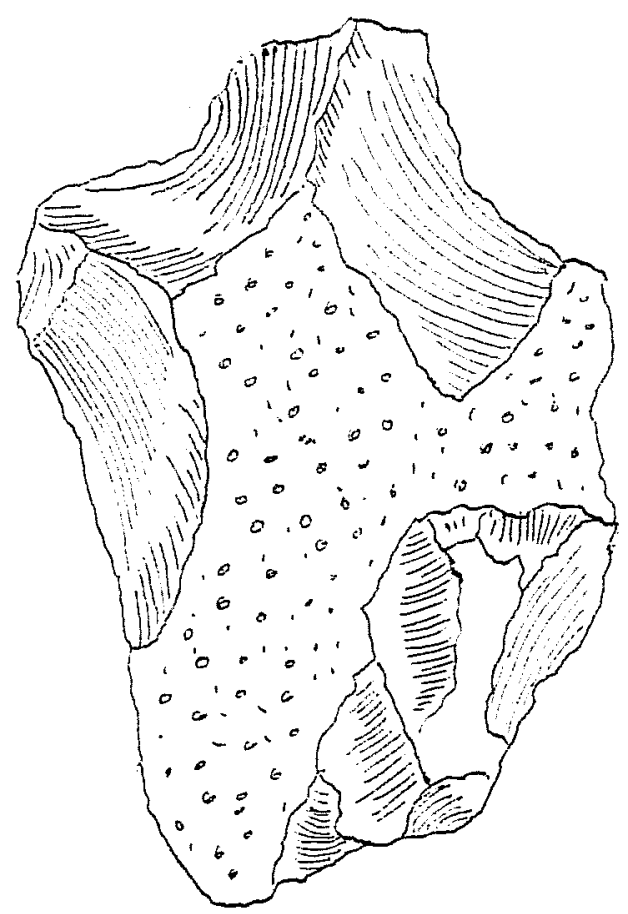

a

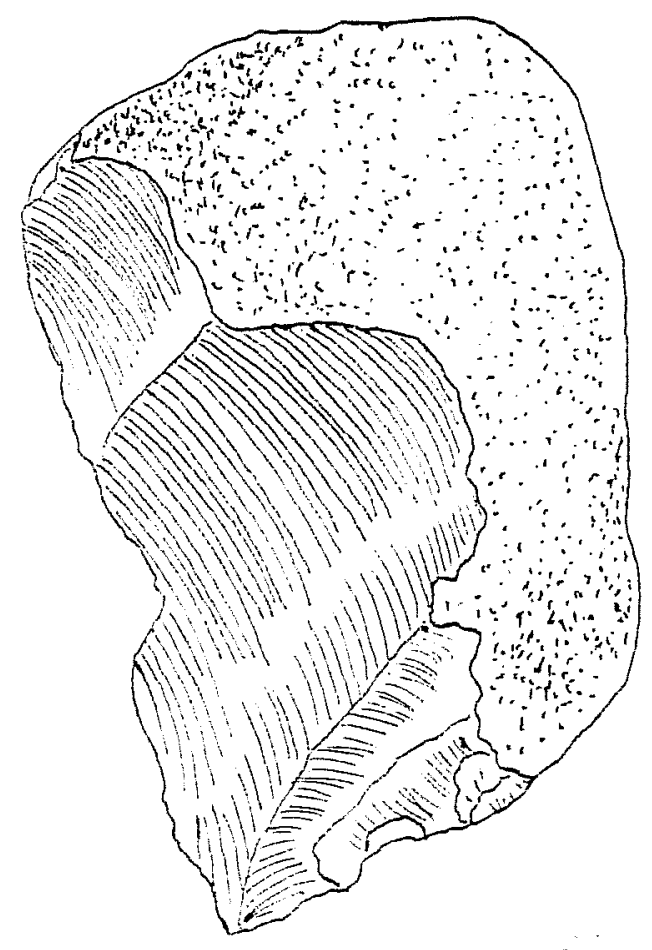

C
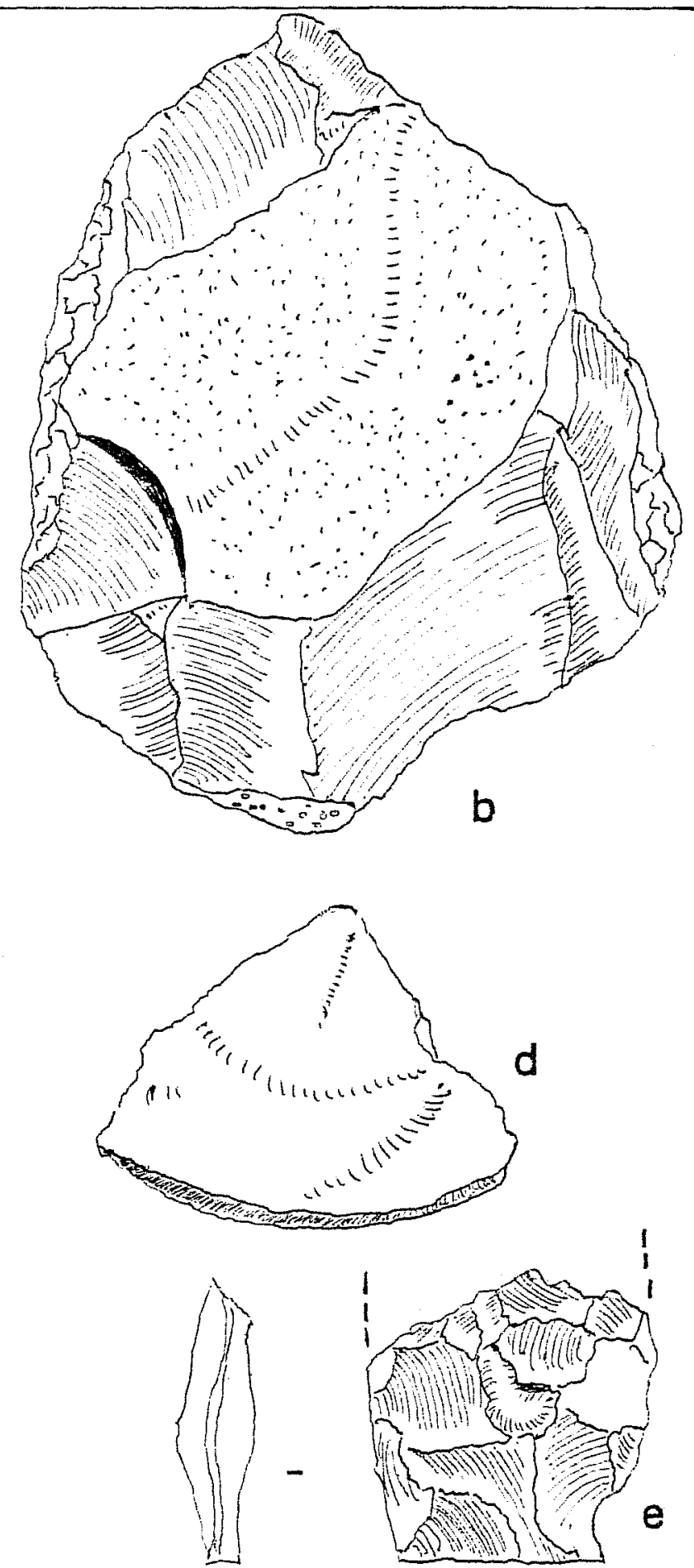

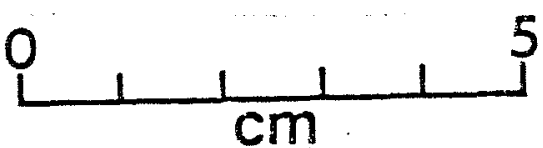

Figure 8. Artifacts from MC $005(41 \mathrm{BX} 462)$. a-c, cores; d, tertiary flake; e, basal section of biface. 


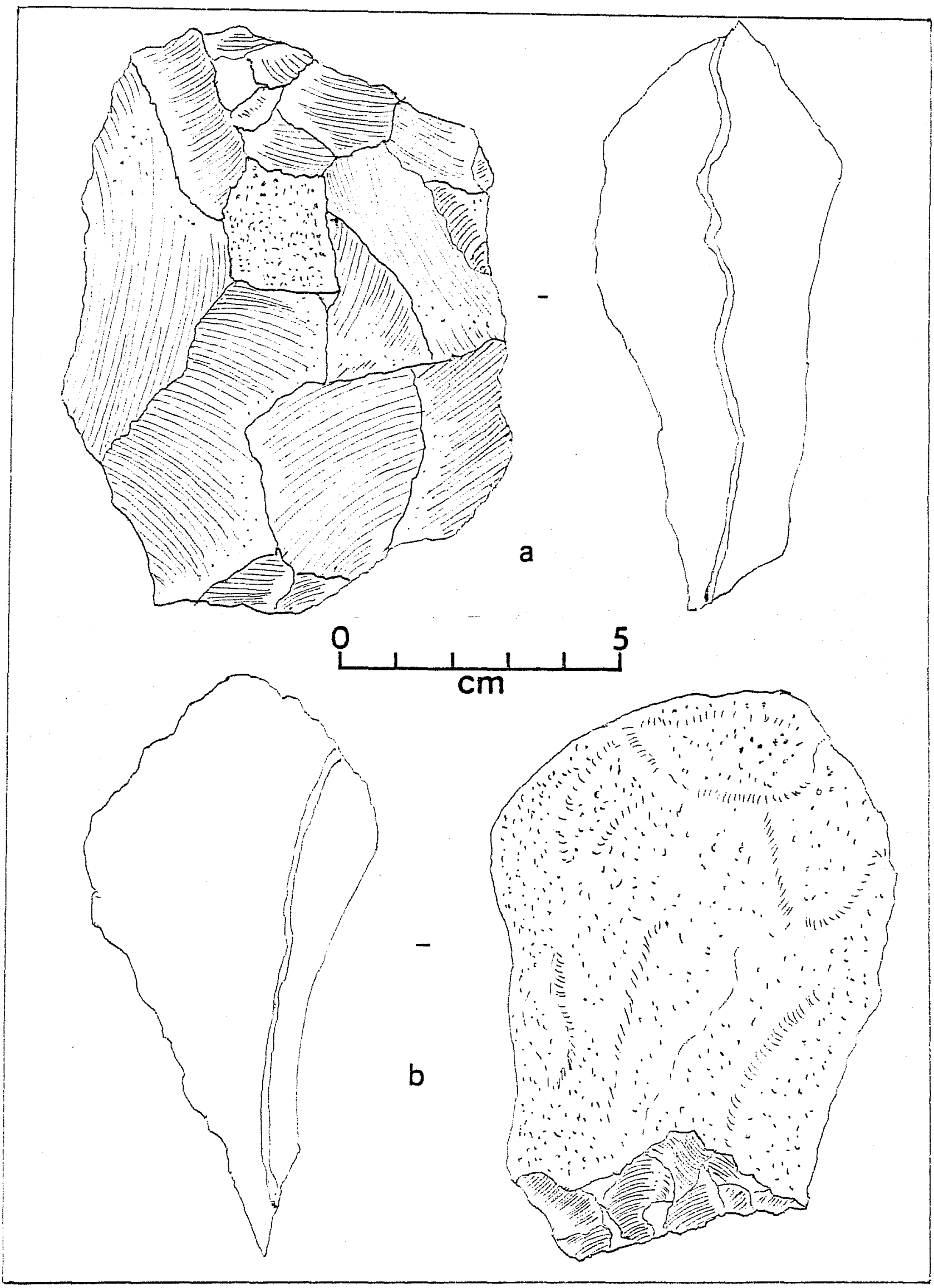

Figure 9. Artifacts from MC $008(41$ BX 465). a, large core; b, large bifacially worked cobble. 

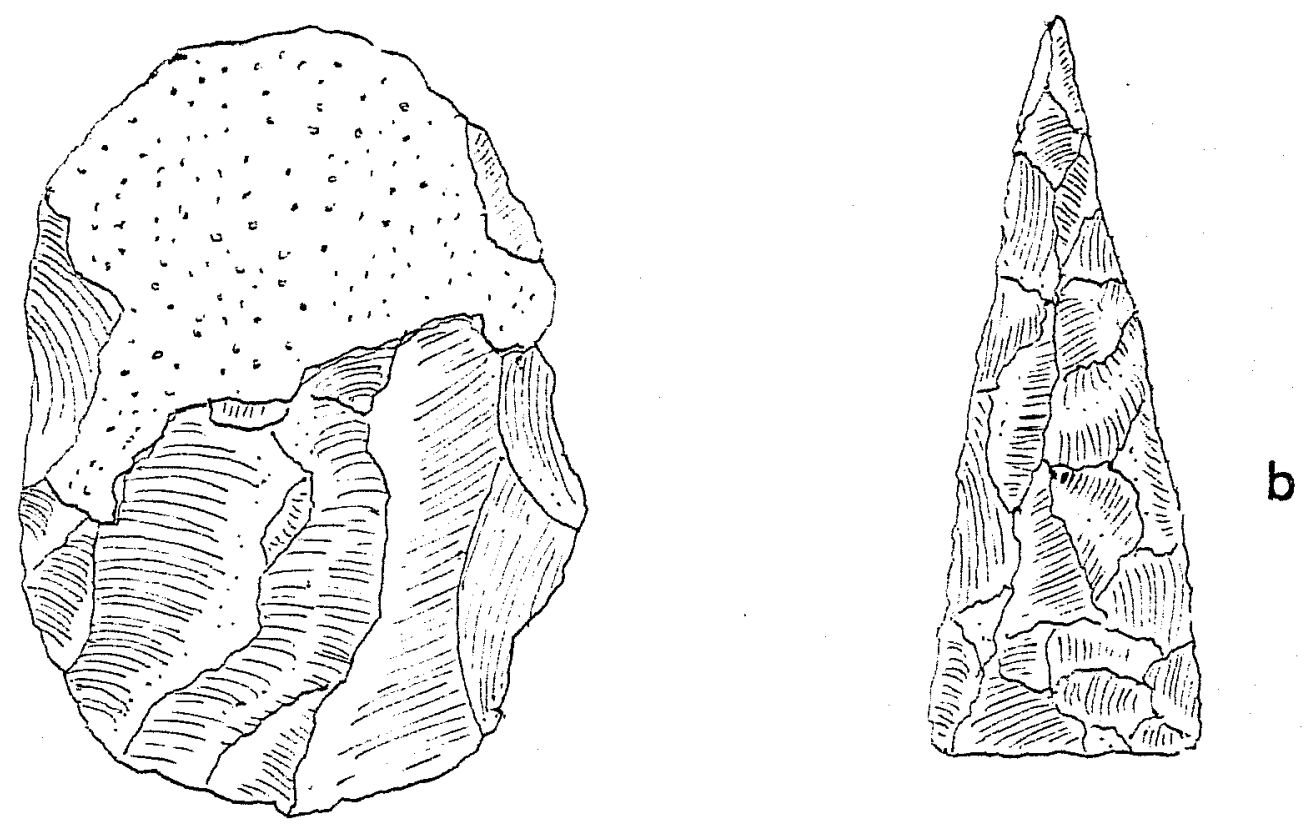

a
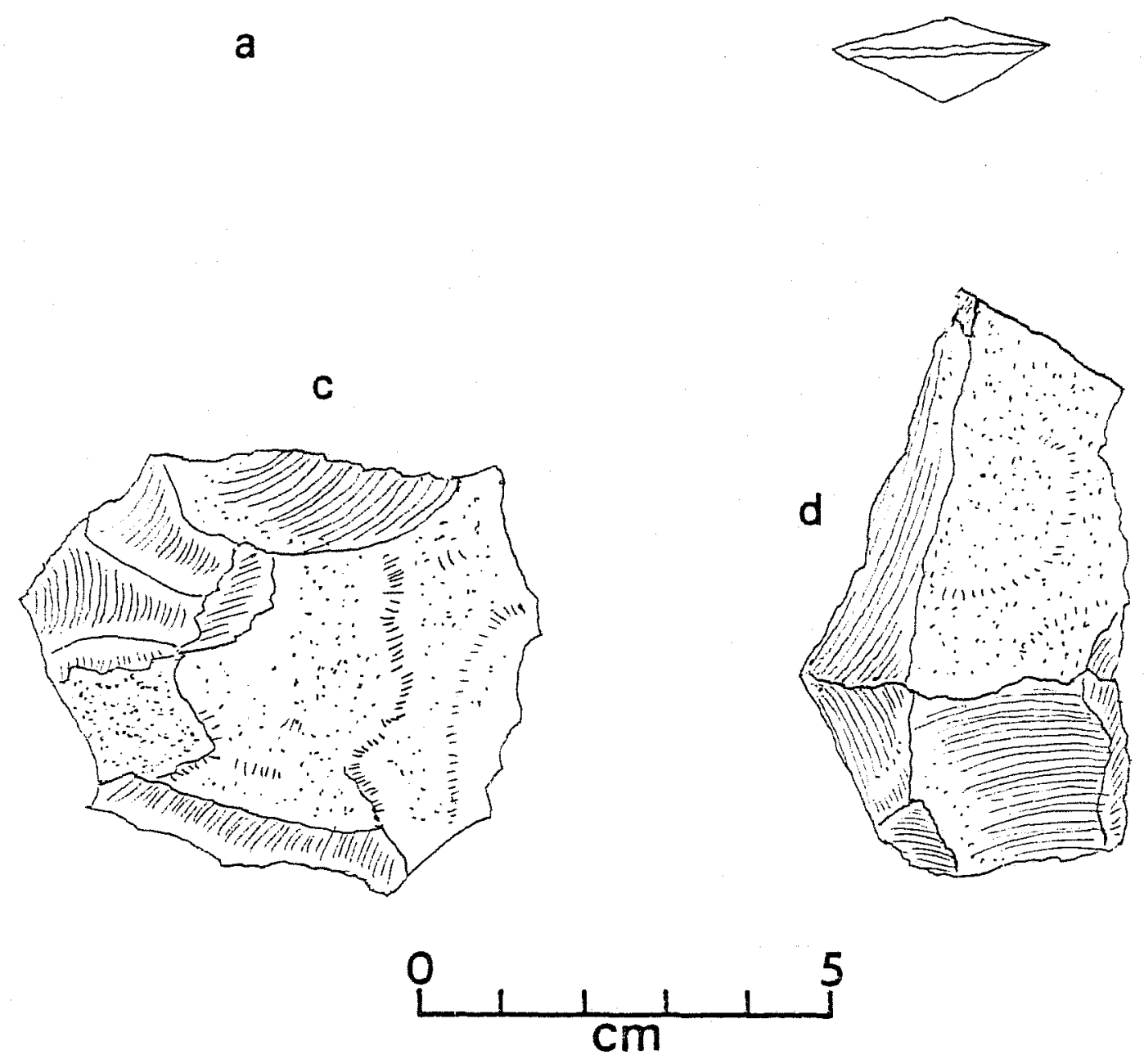

Figure 10. Artifacts from MC 009 (41 BX 466) and MC 010 (41 BX 467). a, bifacially worked cobbie, 41 BX 466; b, Tortugas, 41 BX 467; c, small core, MC 010; d, worked cobble, MC 010. 


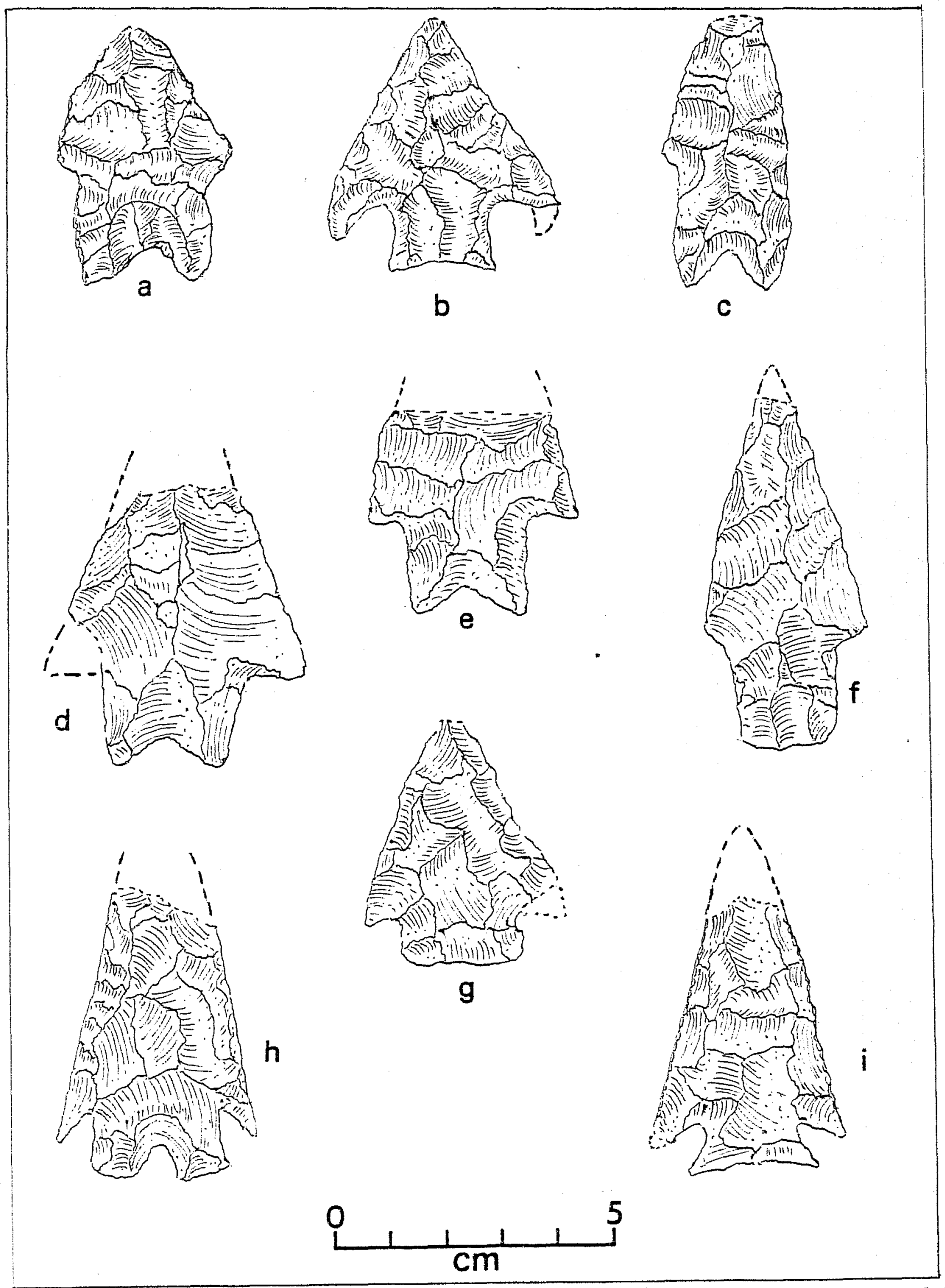

Figure 11. Artifacts from NC 011 (41 BX 468). a, c-e, Pedernales; b, Marshall; $f$, Thavis-like; $g$, wide corner-notched point; h, Montell; $i$, Marcos. 


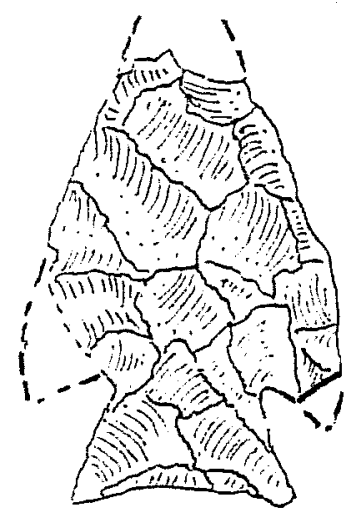

a
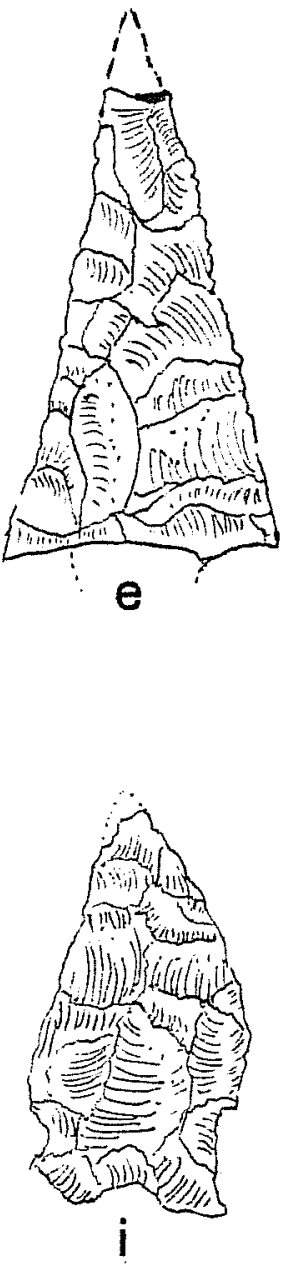
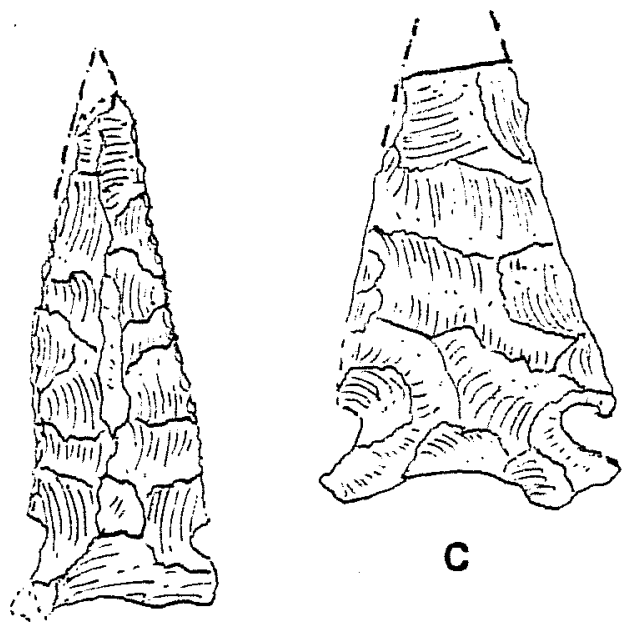

C
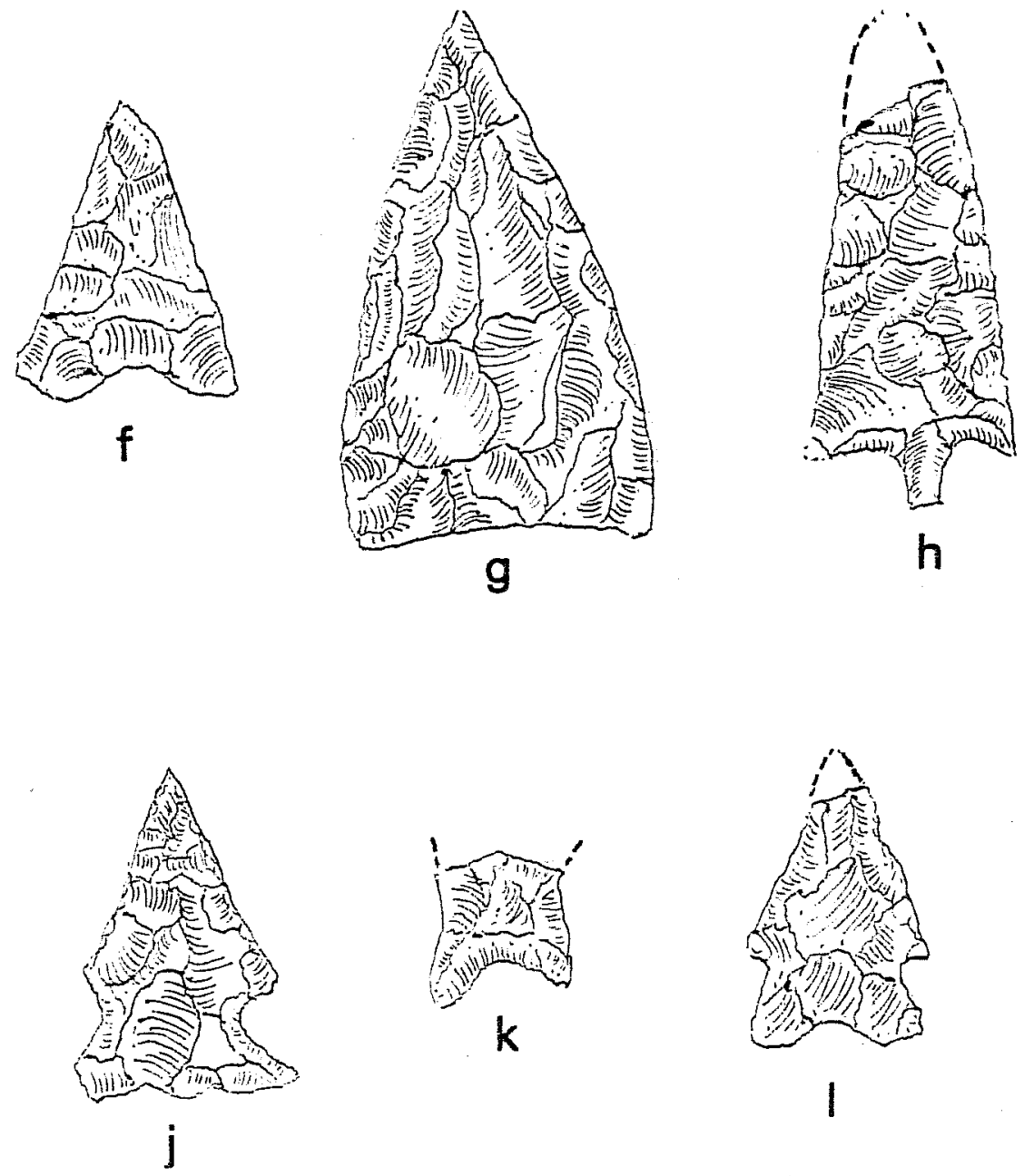

h

$$
\text { d }
$$
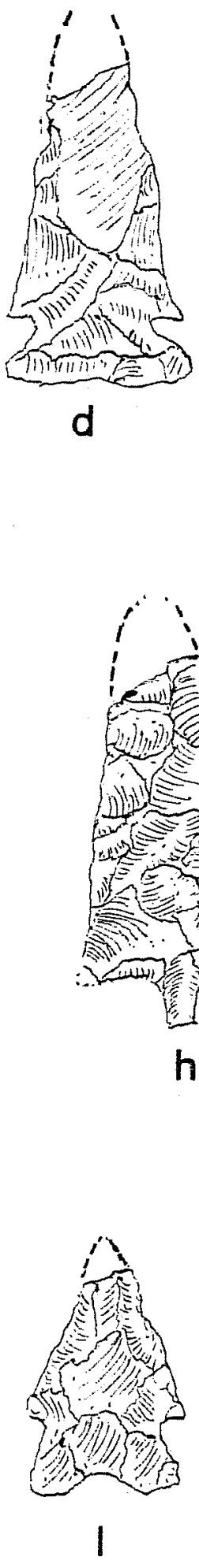
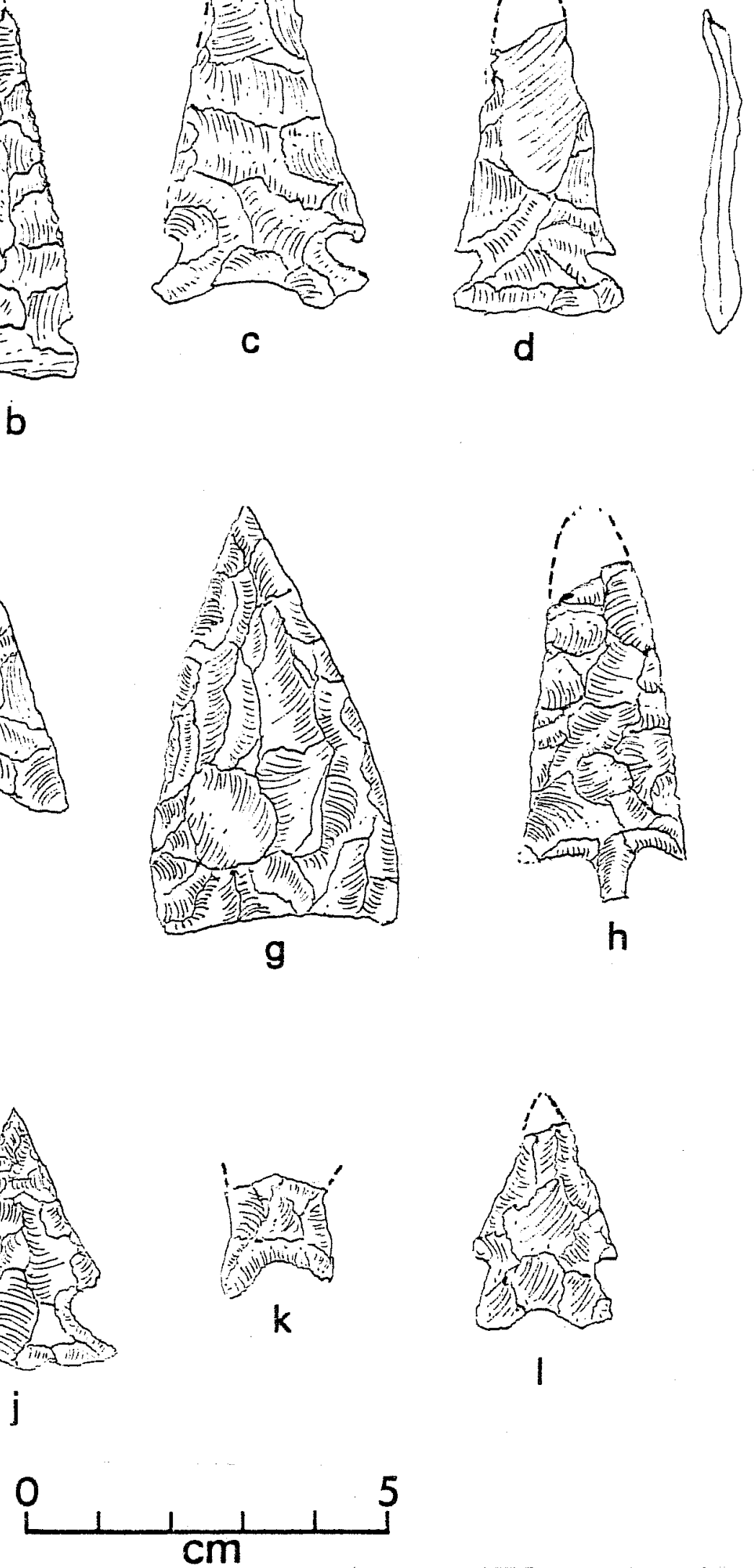

Figure 12. Projectile Points from MC 011 (41 BX 468). a, expanding stemmed point; b, d, j, Ensor; c, f, Frio; e, medial portion of lanceolate point; $\mathrm{g}$, Kinney; h, Perdiz; $i$, basally notched point; $k$, unidentified proximal fragment: 1. Ensor-Frio. 

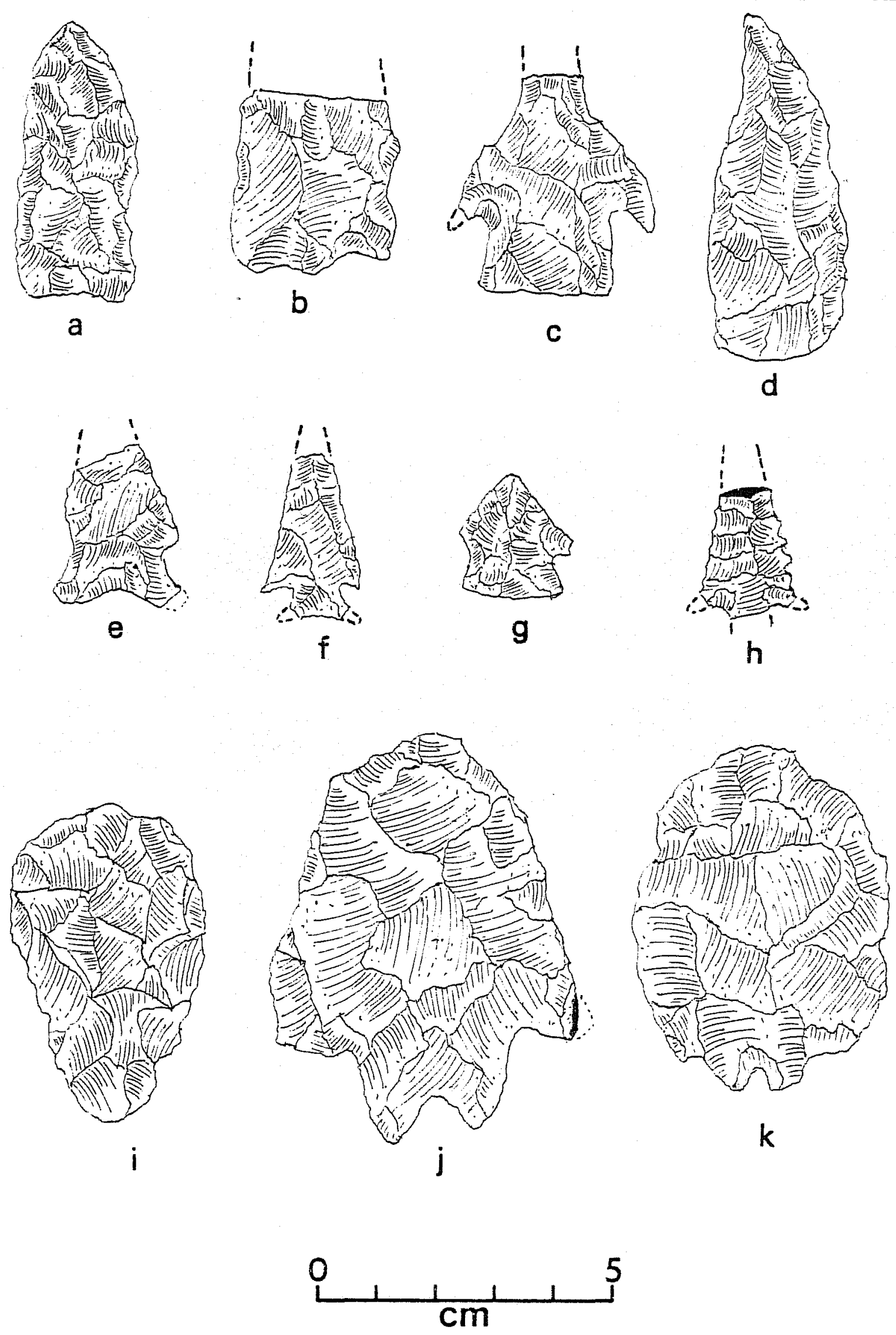

Figure 13. Artifacts from MC 011 (41 BX 468). a, unfinished projectile point; b, proximal portion of unidentified biface; $c$, biface; $d$, small Clear Fork-like tool; e, quartz point Eragment; $f$, corner notched point; $\mathrm{g}$, side notched point; $h$, medial portion of serrated blade; $i$, thick biface; 


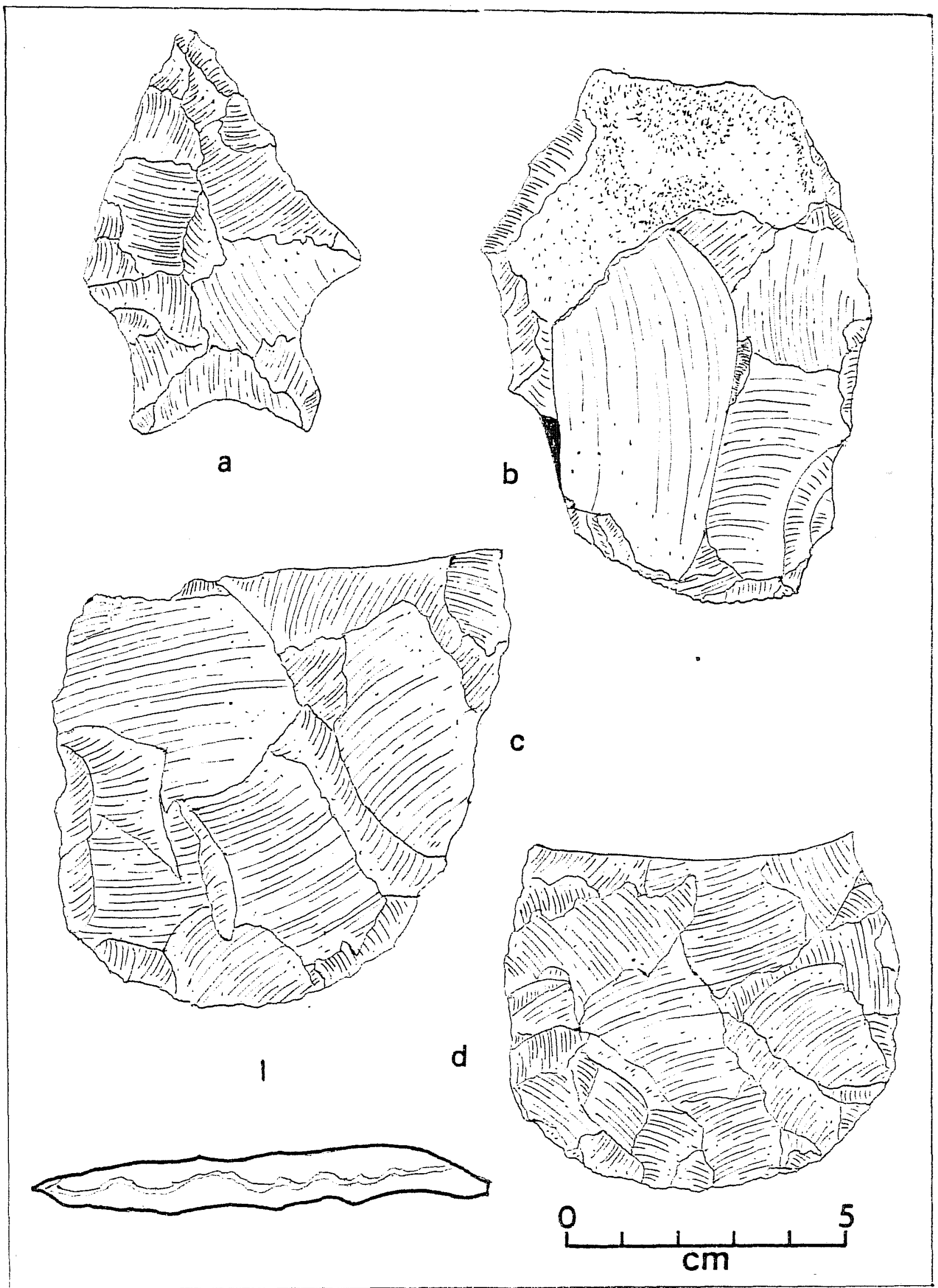

Figure 14. Artifacts from MC 011 (41 BX 468). a-d, large bifaces. 


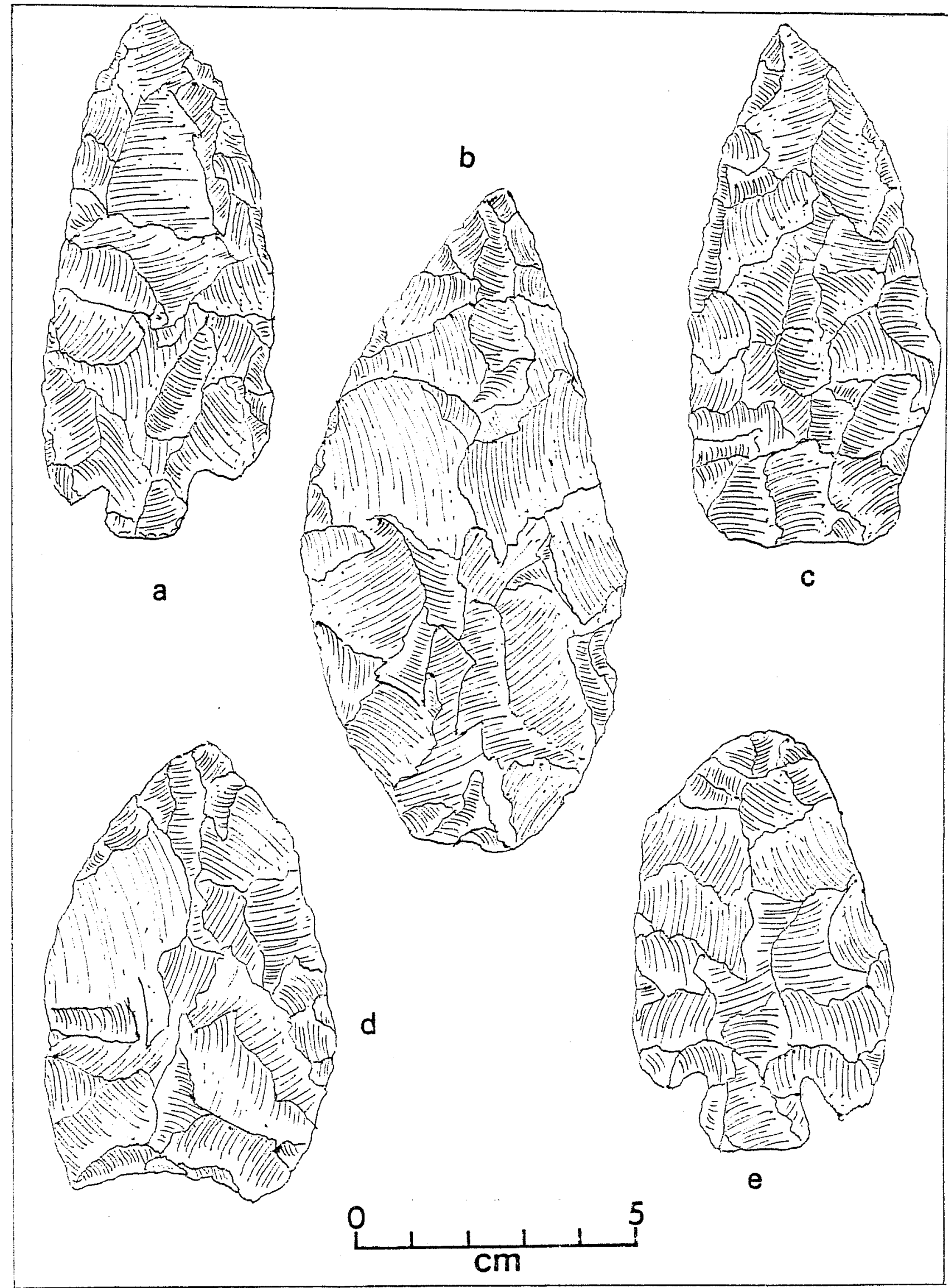

Figure 15. Artifacts from MC $0.11(41$ BX 468). a, large, corner notched biface; b, large, leaf-shaped biface; c, large biface; d, large biface with concave base; e, large, corrier notched biface. 

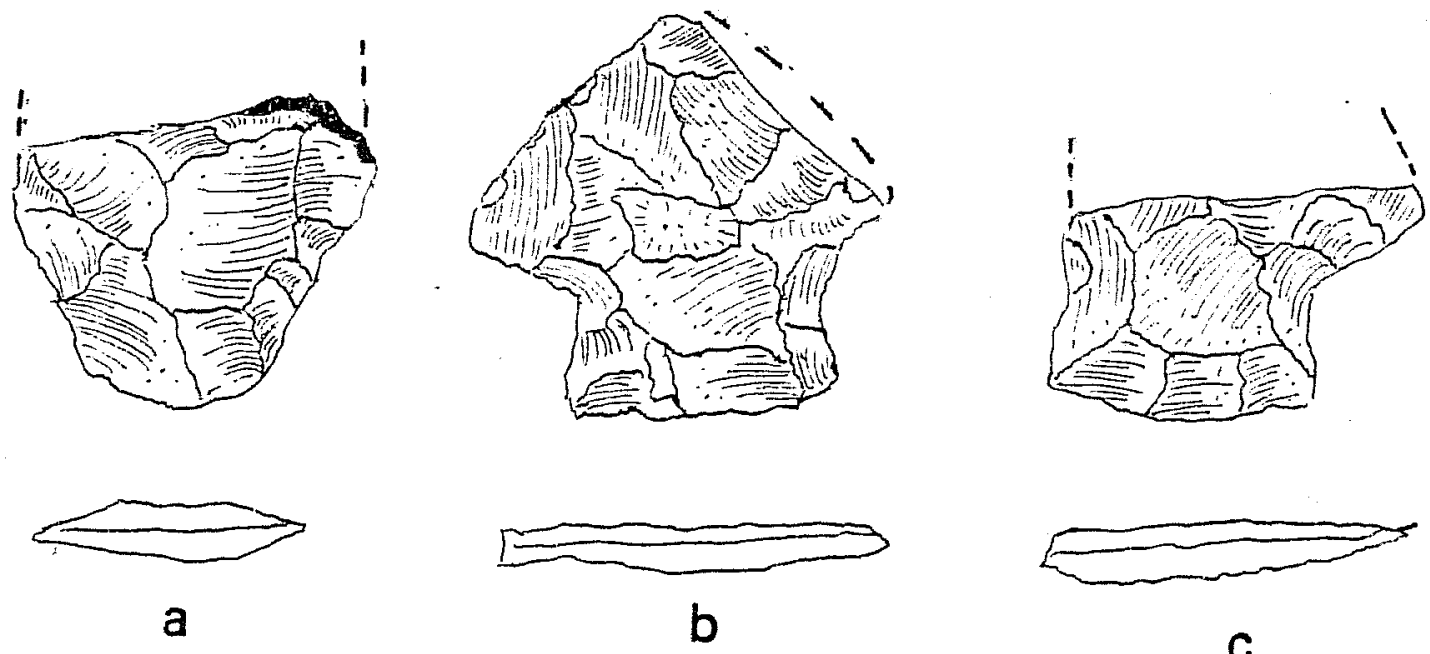

a
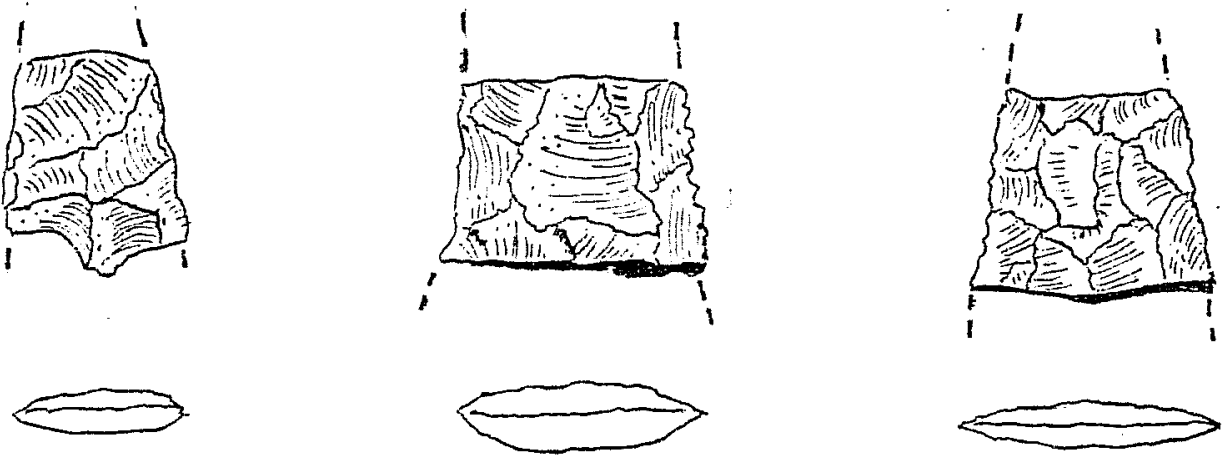

d

e
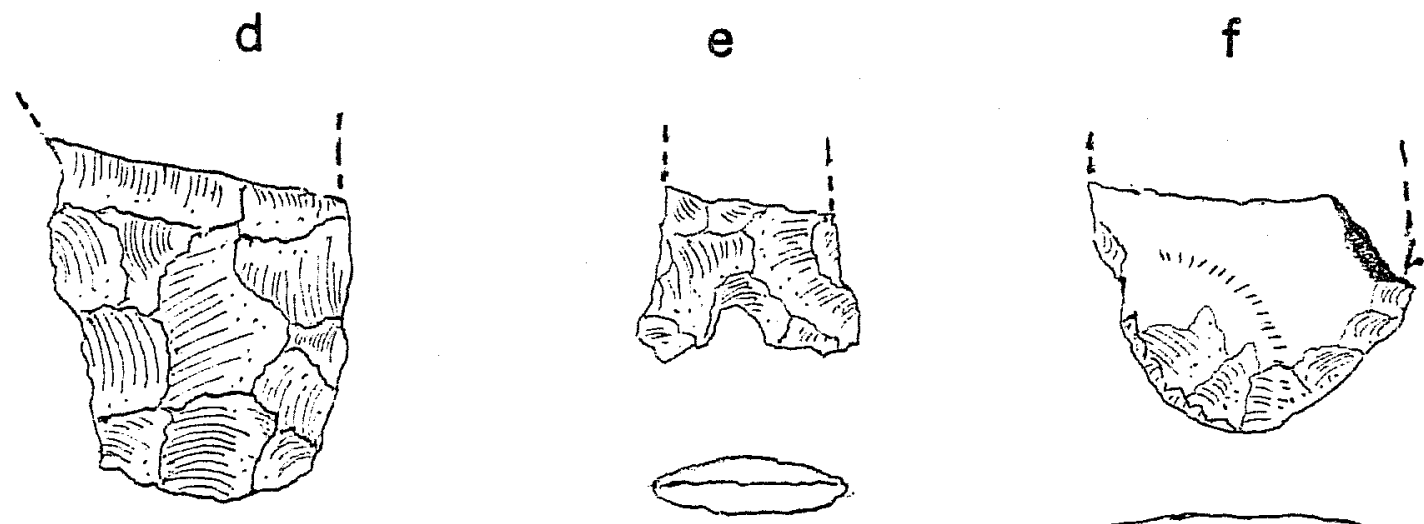

h

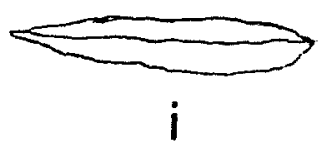

g

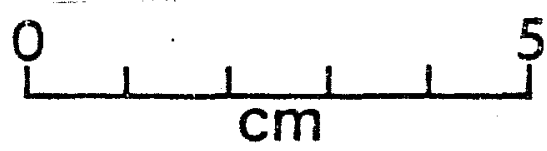

Figure 15. Artifacts from MC $013(41$ BX 470). a, contracting stemmed point; $\mathrm{b}$, expanding stemmed point; $\mathrm{c}$, expanding stemmed point; $d$, medial portion of small biface; e, medial portion of serrated biface; $f$, medial portion of biface; $g$, convex stemmed projectile point; $h$, basally notched biface; $i$, prox- 

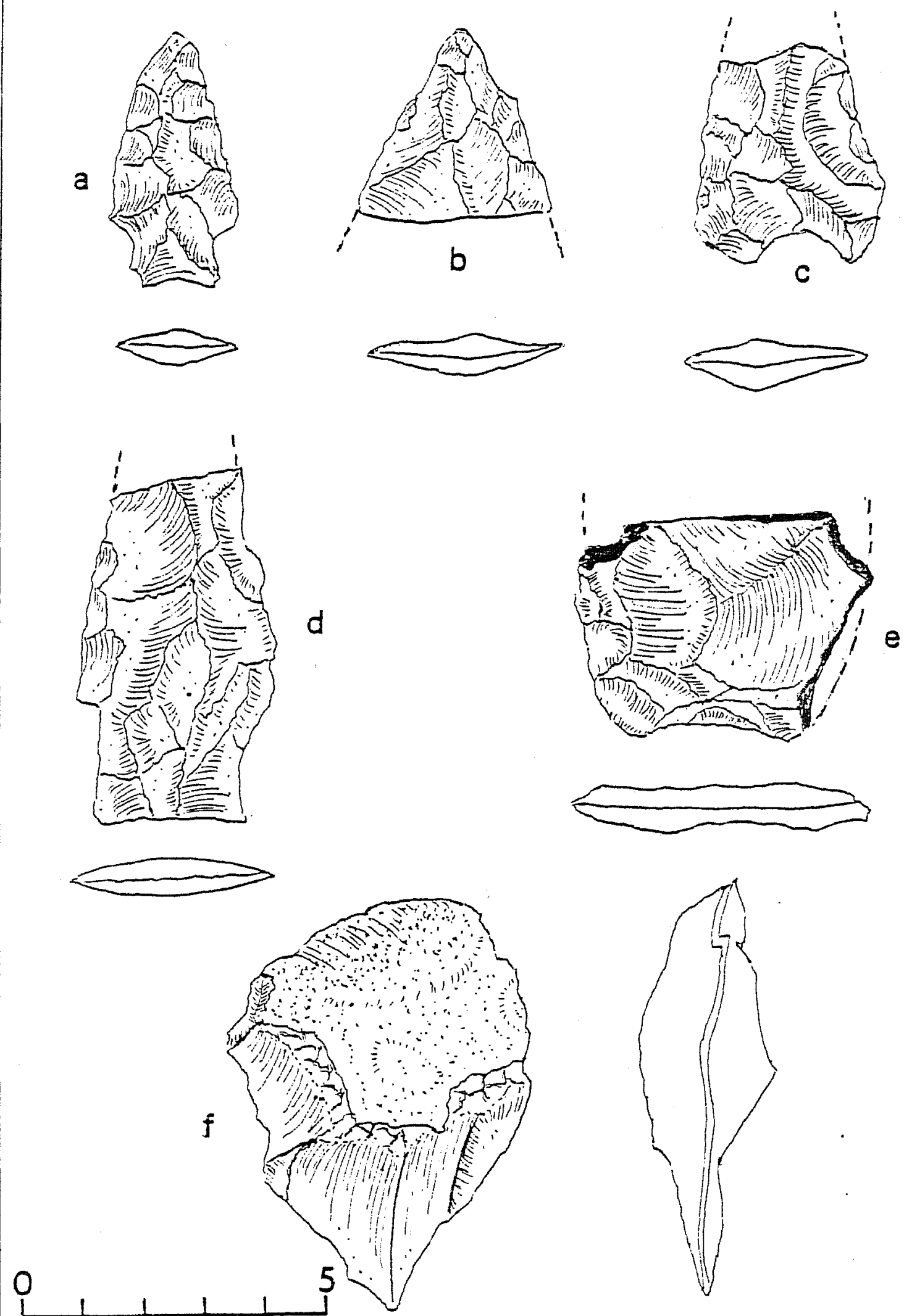

\section{$\mathrm{cm}$}

Figure 17. Artifacts from MC $014(41 \mathrm{BX} 471)$ and MC 015 (41 BX 472). a, corner notched point, MC 014; b, distal portion of biface, MC 014; c, concave base projectile point, MC 015; d, fragment of large, stemmed dart point, MC 015; e, proximal fragment of large biface, MC 015; f, worked lithic fragment, MC 014. 


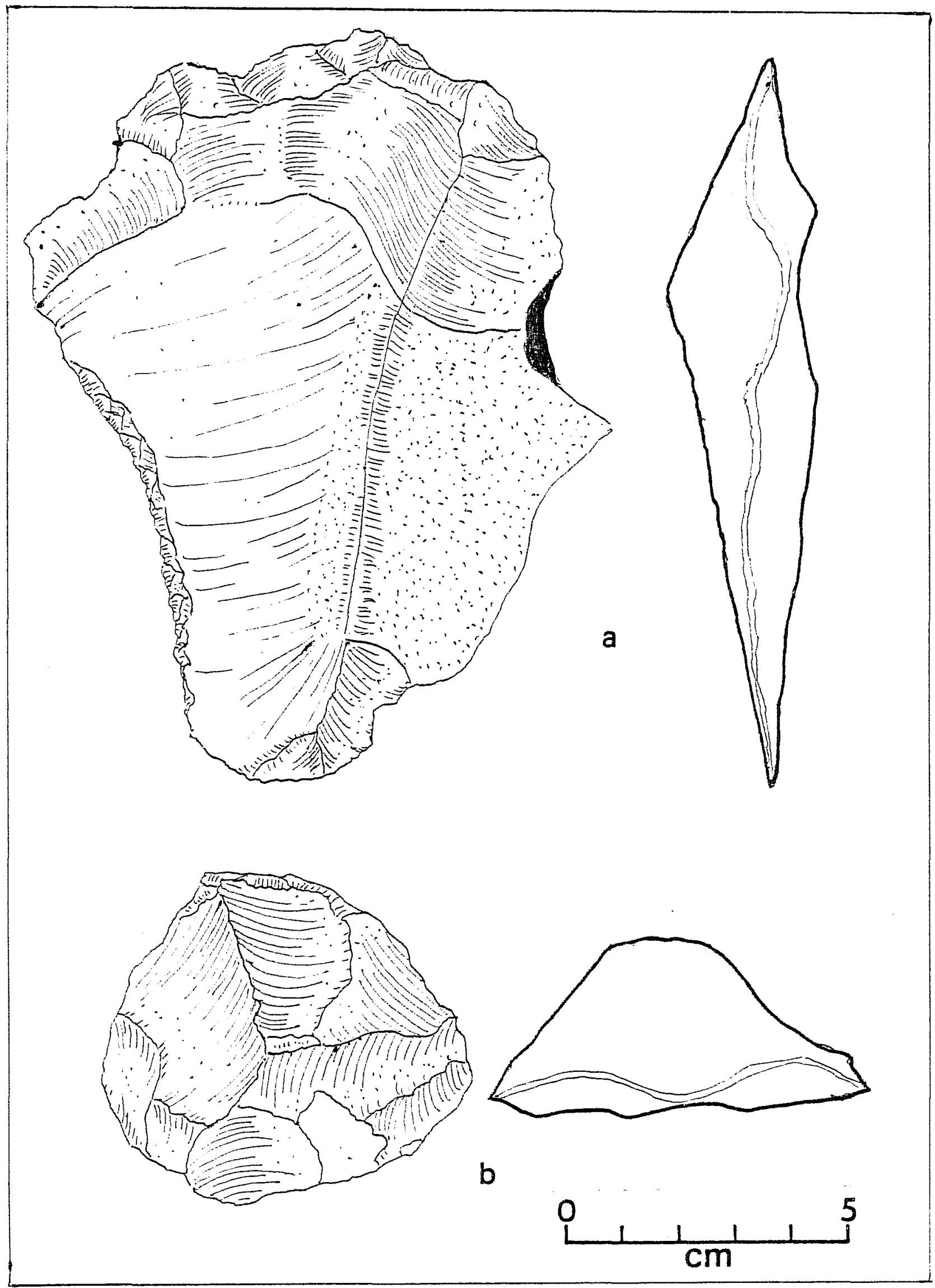

Figure 18. Artifacts from MC 013 (41 BX 470). a, large, thin biface; b, thick biface. 


\section{SUMMARY AND RECOMMENDATIONS}

Fifteen archaeological sites were examined and a preliminary assessment has been made of their potential. Although scattered along the length of Medio Creek, viewed together they form an intermittent chain of sites which reflect the activities of aboriginal hunting and gathering groups.

An unfortunate limitation of this study was its emphasis on sites usually within $400 \mathrm{~m}$ of the creek channel. Marginal upland areas were not usually considered due to limitations of time and manpower. If such sites do exist and are found and identified in the future, they could provide important evidence in locating "base camps" and satellite areas in which specific activities were performed.

Whatever conclusions are derived from this report, the reader must be aware of the environmental changes along Medio Creek, both prehistoric and recent, which could or have altered former conditions for habitation. Such factors include changes in the water table, modern daming of feeder streams, areal rechannelization, natural erosion, and possible storm/sewer run-off into the creek from nearby suburban areas. These elements, along with the possibility of springs along the drainage system, have already modified various segments of the channel to such an extent that the Medio Creek of today may be but a shadow of the waterway once exploited by various Indian groups.

An unusual aspect of the creek noted during the survey was the fluctuation in the water level in different areas of the creek, varying from being completely dry to reaching depths of 12 to 15 feet. Explanations of this phenomenon may include the appearance of springs along the waterway, although the area from which these seem to originate, just north of Highway 90 West, is generally south of the Edwards aquifer recharge zone. Another explanation offered by several landowners living in this area for the past 10-20 years or longer suggests the source of much of this water may be caused by storm/sewer runoff or run-off indirectly caused by nearby suburban development; for example, the watering of lawns in nearby communities.

The survey identified 15 sites along Medio Creek and a division of sites by major activity through preliminary analysis suggests the following breakdown:

I. Occupation sites........... . . .11

1) within 10-15 m of creek ..... . 3

2) occupation sites within $15 \mathrm{~m}$ of creek north of Hwy 90 west... . . 5

II. Lithic workshop site . . . . . . . . 4

1) Iithic workshop sites located in upland areas... . . . . . . . 4 
Preliminary observations suggest differences in habitation patterns along the drainage system. In the area of $\mathrm{Hwy} 90$ and southward, archaeological evidence is scattered over broad areas commonly as large as $300 \mathrm{~m}$. These "activity zones" are contrasted to the smaller, specific sites more common along Medio Creek north of Hwy 90. All identified occupation sites to the north of this area are located within $15 \mathrm{~m}$ of the creek channel on low stream terraces. The one exception to this is MC 014, located on a knoll ca. 0.25 mile from the present channel; however, a series of broad terrace remnants may suggest the creek meandered across much of the areal floodplain in the past.

Diagnostic artifacts, especially projectile points, from different areas of the creek suggest different cultural groups occupying these sites at different times. The presumed mobility of local hunting and gathering groups occupying this region in the past implies several possibilities for various occupational patterns of the drainage. Two of the most obvious are: (1) similar groups were seasonally exploiting different resources of the creek over generations; and/or (2) different cultural groups, as reflected by the variety of point styles, intermittently inhabited specific areas of the creek. From artifact analysis alone, the northern portion of Medio Creek is more intensively occupied through the Archaic period and in the Late Prehistoric. The presence of pottery in two separate southern sites indicates Late Prehistoric or possible early Historic occupation with some contact with Indian cultures beyond the south Texas region.

Table 1. Summary of Recommendations for Future Research

Site

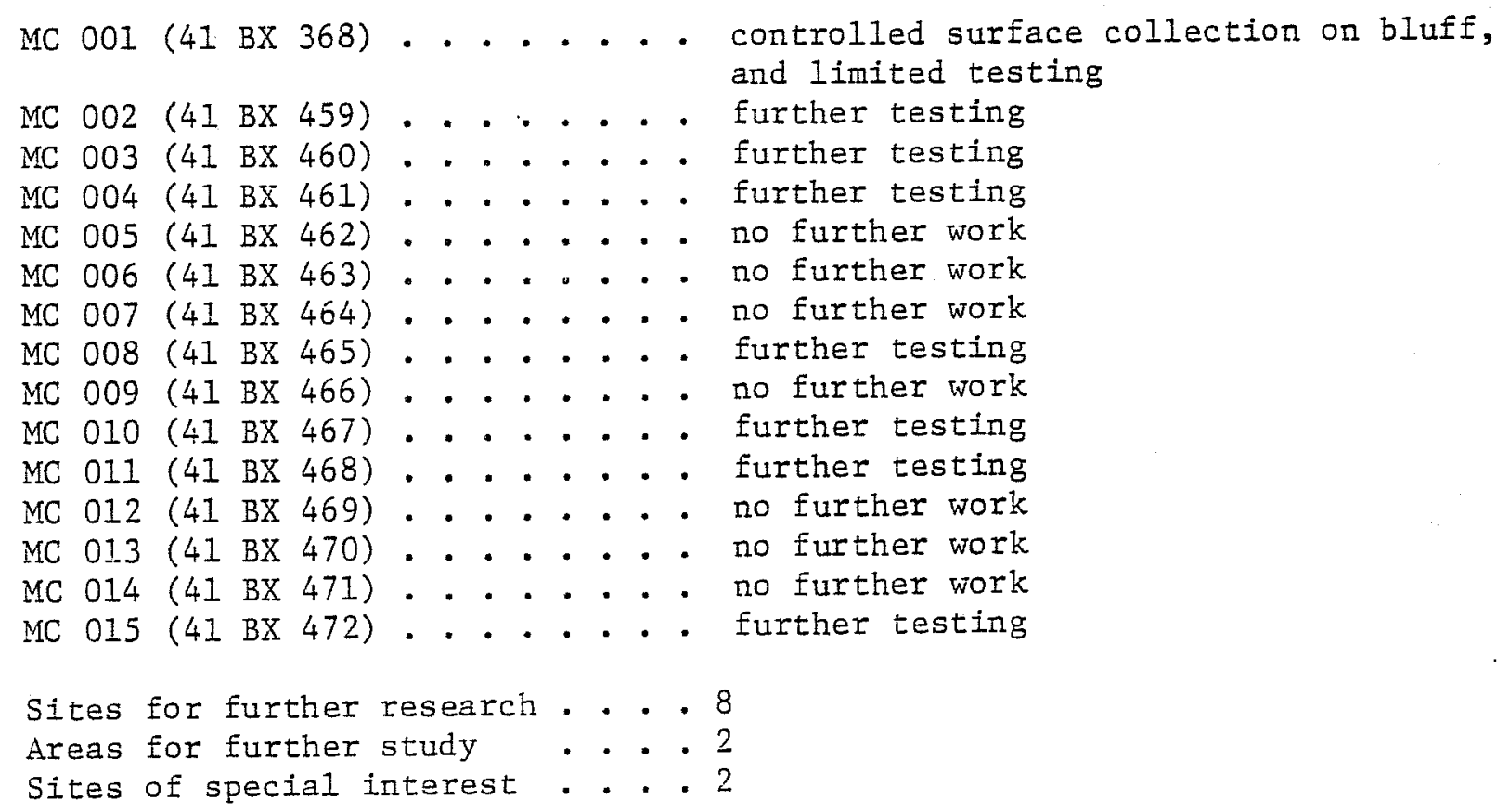

Recommendation/Assessment and limited testing$$
\text { further testing }
$$$$
\text { further testing }
$$$$
\text { no further work }
$$$$
\text { no further work }
$$$$
\text { no further work }
$$$$
\text { further testing }
$$$$
\text { no further work }
$$$$
\text { further testing }
$$$$
\text { further testing }
$$$$
\text { no further work }
$$$$
\text { no further work }
$$$$
\text { no further work }
$$ 


\section{ACKNOWLEDGMENTS}

While conducting the survey it was often necessary to obtain permission from various landowners to enter their property, and their cooperation and courtesy is gratefully acknowledged. This writer is especially indebted to $\mathrm{Mr}$. and Mrs. R. J. Prosise, Mr. and Mrs. R. H. Tucker, Mrs. G. DeFriese, Mr. H. Stolte, Mr. V. King, Mr. and Mrs. B. Turner, and Mrs. Cindy McGraw for their friendly interest and helpfulness.

The field work was performed as a semester project for ANT 4113 ("Texas Archaeology") and was under the general direction of $\mathrm{Dr}$. T. R. Hester, The University of Texas at San Antonio. 
Blair, W. F"

1950 The Biotic Provinces of Texas. Texas Journal of Science $2(1): 93-113$.

Fawcett, W. B., Jr.

1972 The Prehistory of Bexar County: A Study of Previous Work in South Central Texas. Bulletin, Lower Plains Archaeological Society 2 (1971):23-44.

Hester, Thomas R. (assembler)

1975 Archaeological and Historical Resources in the San AntonioGuadalupe River Basins: A Preliminary Statement. The University of Texas at San Antonio, Center for Archaeological Research, Regional Studies 1.

Hester, Thomas R., R. F. Heizer and J. A. Graham

1975 Field Methods in Archaeology. 6th Edition. Mayfield Publishing Co., Palo Alto, California

Nunley, P. and T. R. Hester

1975 An Assessment of Archaeological Resources in Portions of Starr County, Texas. The University of Texas at San Antonio, Center for Archaeological Research, Survey Report 7.

Taylor, F. B., R. B. Hailey and D. I. Richmond

1966 Soil Survey of Bexar County, Texas. U.S. Department of Agriculture, Soil Conservation Service, Series 1962.

Woolford, S. W.

1935 Types of Archaeological Sites in Bexar County, Texas. Witte Museum, Archaeological Bulletin 4. 